\title{
TITLE: INFLUENCE OF SOCIOECONOMIC STATUS AND STRESS OVER QUALITY OF SLEEP: A SYSTEMATIC
}

\section{REVIEW}

1- Faustin Armel Etindele Sosso, PhD, Research Center of Neurosciences, Center for Advanced Studies in Sleep Medicine, Hopital du Sacré-Coeur de Montreal, Montreal, Québec, Canada ${ }^{a}$

2- Aarti Jagannath, PhD, Nuffield Department of Clinical Neurosciences, University of Oxford, Oxford, United Kingdom $^{b}$

3- Fabricio Ferreira De Oliveira, PhD, Department of Neurology and Neurosurgery, Universidade Federal de São Paulo, Sao Paulo, Brazil c

4- Salim R. Surani, PhD, Department of Medicine, Texas A\&M University System Health Science Center, Bryan, Texas, United States ${ }^{\mathrm{d}}$

5- Vincent Mysliwiec, MD, Pulmonary and Sleep Medicine, Madigan Army Medical Center, Tacoma, Washington, United States e

\section{Citation: Faustin Armel Etindele Sosso ${ }^{\mathrm{a} *}$, Aarti Jagannath ${ }^{\mathrm{b}}$, Fabricio Ferreira De Oliveira ${ }^{\mathrm{c}}$, Salim R. Surani ${ }^{\mathrm{d}}$, Vincent Mysliwiec $^{\mathrm{e}}$. Influence of Socioeconomic Status over Quality of Sleep: a Systematic Review. Preprints 2018}

\section{SUMMARY}

Sleep disorders (SD) have a complex aetiology, and socioeconomic status (SES) as determined by social class, household income, ethnicity and education plays an important role in their development. As SD are associated with cognitive impairment and mood disorders, they in turn impact SES. Socioeconomic status also influences allostatic load caused by chronic accumulation of stress throughout life. Environmental and psychological stressors have a direct effect on SD, and they are modulated by SES, in combination with comorbidities like obesity and cardiovascular disease. This review explores the recent theories about the influence of SES on the development of SD in the general population, whether or not occurring with comorbidities, and also focusses on the interplay between socioeconomic status, circadian rhythms, aging and clinical outcomes like metabolic diseases and cancer.

Keywords: sleep, socioeconomic status, stress, circadian rhythm, allostatic load, mood disorder, social class 


\begin{tabular}{|lll}
\hline Abbreviations & & \\
SD: sleep disorders & CR: circadian rhythm & VLPO: ventrolateral preoptic area \\
SC: social class & CC: circadian cycle & REM: rapid eye movement \\
SES: socioeconomic status & BMI: body mass index & SCN: suprachiasmatic nuclei \\
MD: mood disorders & TTFL: transcription-translation feedback loop & \\
\hline
\end{tabular}

\section{$\underline{\text { INTRODUCTION }}$}

Sleep is a physiological state that corresponds to one-third of a human life. Much more than just a passive state, sleep plays a major role in physical and psychological health ${ }^{1}$. Indeed, acute or chronic disruption of sleep can have major consequences on alertness, learning ability, mood, cardiovascular health, the immune system and weight regulation ${ }^{2}$. Sleep is a natural state of loss of consciousness of the external world that does not exclude the reception of sensory information but is accompanied by a progressive reduction of muscle tone and recurs in regular intervals.

The timing of the sleep-wake cycle is driven by two factors, the homeostatic build-up of sleep need and the circadian rhythm (CR) which defines the appropriate temporal niche for sleep ${ }^{3,4}$. Organization of the circadian cycle (CC) leads to alternation between the day before and sleep. Organization of ultradian cycles leads to alternation between slow sleep and paradoxical sleep ${ }^{5,6}$. The primary circadian pacemaker of the human brain is the suprachiasmatic nucleus of the hypothalamus, indirectly connected to the 
ventrolateral preoptic area (VLPO), a hypothalamic structure made up of GABAergic neurons which inhibit the arousal systems, therefore supporting sleep ${ }^{7}$. These processes are supported and maintained by various neurotransmitters like adenosine and histamine ${ }^{8}$. The CC, regulated by internal biological clocks, is aligned with the dawn-dusk cycle (the nychthemeral rhythm) by external synchronizing factors ${ }^{8-10}$. The nychthemeral rhythm leads to lower body temperature due to the action of melatonin, a cerebral hormone that is synthesized by the pineal body during the night. The scheduled secretion of this hormone partly depends upon genetic factors but is also modulated by epigenetic interactions through external stimuli such as luminosity, food supply, social relationships and the production of heat ${ }^{9,10}$. The molecular mechanisms at the origin of this homeostatic process are not fully understood. The result is a nightly sequence of three to five cycles of approximately 90 -minutes of sleep, each one composed of several distinct phases, starting with the slow wave sleep and ending with the paradoxical sleep (when dreams start). It was recently shown that exposure to natural light improves symptoms related to disorders of the cycles of sleep, but research associating melatonin therapy with better sleep is continuously discussed as melatonin shows limited potency and is only applicable in some populations ${ }^{9}$.

During sleep, many neuronal networks are rebuilt, and this mechanism could have explanations and implications for energy processing, metabolism and memory ${ }^{9,11}$. Consolidation of the information received during the wake phase of the day is carried out during sleep, due to inhibition of the cerebral activity supporting processes of homeostatic plasticity of the different neural networks 12,13. The need for sleep (often termed sleep debt) varies from person to person, but also with cultural influences, geographical location and the practices of life. The ideal mean length of sleep for an adult would be eight hours per day, but it usually varies between six and ten hours per night, also affected by factors that may predispose to sleep disorders (such as age, the presence of a neurological disease and the exposure to intense psychological or environmental stress). 
Sleep disturbances or sleep disorders (SD) have many and varied causes, such as stress, mood disorders (MD), lifestyle habits, living conditions, diseases or aging ${ }^{14,15}$; and they are often associated with some clinical outcomes such as cognitive impairment and breathing abnormalities ${ }^{8,16}$. The spatial distribution of SD within a population is influenced by sociodemographic variables like age, sex, profession and comorbidities ${ }^{17,18}$. Socioeconomic status (SES), and thus living conditions, lifestyle habits, stress, physical and mental health and aging ${ }^{14,16,19-22}$ can all influence the development and progression of SD. The variations in SES within the population correspond to variations in the level of access to different conditions and resources favorable to health ${ }^{22-24}$. While SES is an important determinant of health, its role in the development and maintenance of SD is not well studied. SES may induce some form of stress, often complex to figure out mainly because of the difficulty to evaluate the direction of this relationship ${ }^{25,26}$. This chronic accumulation of stress becomes a progressive burden (known as allostatic load); and correlation or association between the socioeconomic factors inducing psychological and environmental stress and the trajectory of SD remains unclear.

This review explains the recent theories about environmental and psychological stress in the context of different SD documented in current literature. Following that, the review gives a detailed synthesis of existing interactions among allostatic load, SD, SES and clinical outcomes like cancer, metabolic diseases, neurodegenerative diseases and circadian rhythm disturbances. Finally, the authors provide a theoretical model explaining how this interaction works, emerging from the current state of the knowledge and how researchers may improve current practice.

\section{METHOD}

Using PRISMA (Preferred reporting items for systematic reviews and meta-analyses) guidelines, a comprehensive literature search was performed on articles published in peer-reviewed journals from June 1974 until March 2018, according to the following 
types of studies: clinical, experimental, quasi-experimental and epidemiological. The databases used for this review were the following: PubMed, Web of Science, PsycINFO. We crossed the term "socioeconomic" with "social class" (55415 articles found). After that, the results were associated with the term "sleep" (623 articles found), then this syntax was crossed with the term "stress" (101 articles found). The final items were screened and reviewed in combination with Google Scholar, allowing us to identify the fulltext manuscripts. Google Scholar was also useful to identify the most relevant references for our subject. The inclusion criteria upon which the studies were selected were: (i) the inclusion of empirically collected data (ii), an assessment of SD in some form (iii), the inclusion of human participants aged from 18 to 90 years old in the sample (iv), articles published in peer-reviewed journals (v), fulltext availability (vi), an assessment of SES and SC in some form (vii), an assessment of stress, cortisol, anxiety and depression (vii) and (viii) written in either English or French. Methodological papers, editorials, opinion articles, policy and commentary papers were excluded. Papers focusing on one disease only (obesity, heart failure, etc.) in association or in correlation with sleep disturbances without assessing SES, or articles reporting only sleep disturbances without association or correlation with socioeconomic or sociodemographic factors were excluded. Research reporting stress or sleep problems related to natural disasters and stressful life events such as death of a close relative or moving from a location to another were also excluded. Articles on SES reporting associations, correlations or influence of psychological and social stressors on sleep problems were retained. Following this rigorous literature compilation, 23 empirical studies met the inclusion criteria. After reading and analyzing full texts and extracting data, 19 articles were considered interesting for the topic and selected for review. 


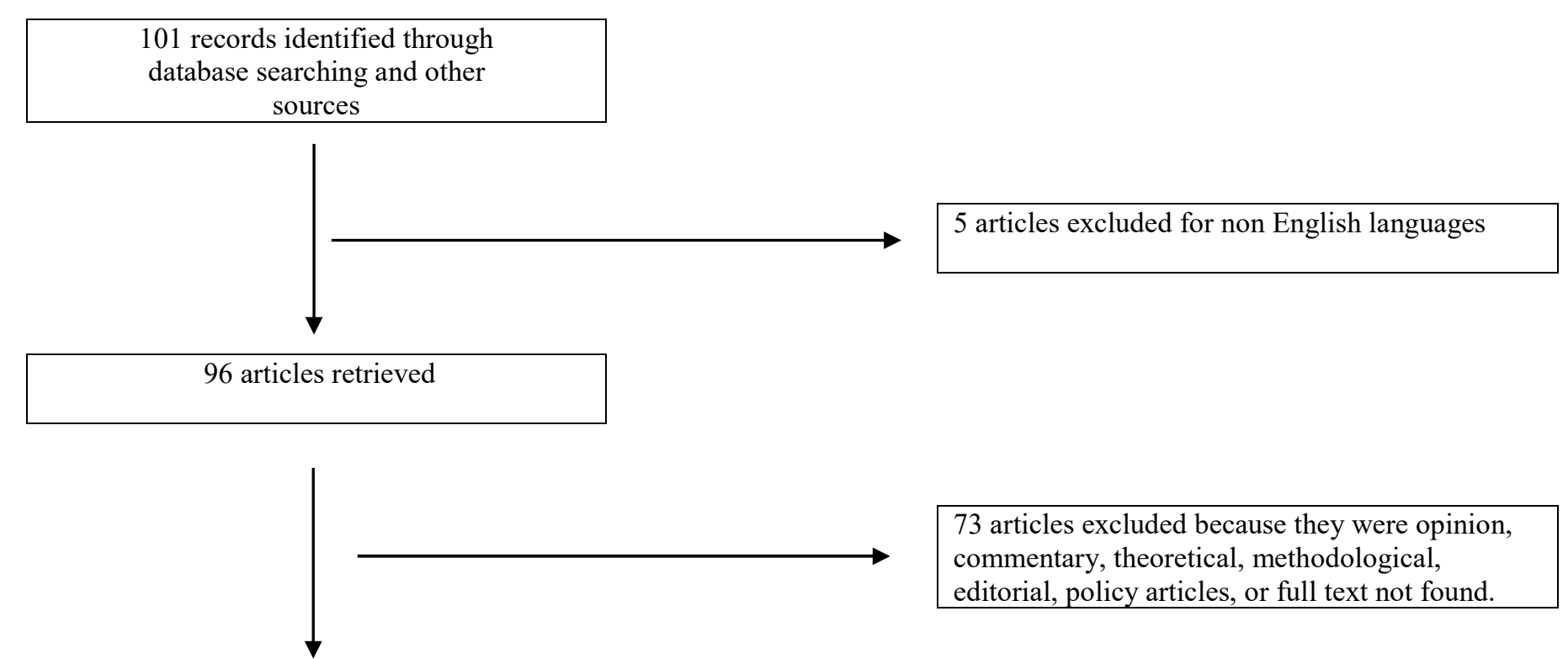

23 full papers of empirical studies evaluated in

qualitative synthesis

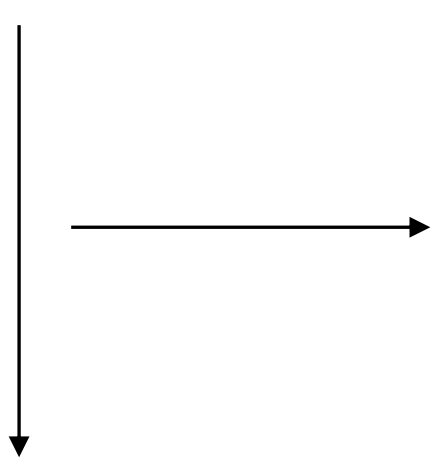

\author{
4 studies removed because: \\ -1 study used social support without financial, income, household \\ measures. \\ -1 study considered social discrimination as lower SES without \\ income, education, household measures. \\ -2 studies evaluated effects of social relation of participants on sleep \\ difficulties without assessing SES.
}

19 studies included in quantitative synthesis

Fig 1: Flow chart for identifying eligible studies 


\begin{tabular}{|c|c|c|c|c|c|}
\hline References & Aims & Population & Materials and Methods & Variables/Measures & Main Conclusions \\
\hline $\begin{array}{l}\text { Hoggard and } \\
\text { Hill, } 2016^{27}\end{array}$ & $\begin{array}{l}\text { To examine the } \\
\text { involvement of } \\
\text { components of } \\
\text { perseverative } \\
\text { cognition in the } \\
\text { association } \\
\text { between } \\
\text { ethnicity and } \\
\text { subjective } \\
\text { sleep quality. }\end{array}$ & $\begin{array}{l}68 \text { self- } \\
\text { identified } \\
\text { African } \\
\text { American } \\
\text { college students } \\
(55.9 \% \\
\text { female; Mean } \\
\text { age }=20.18, \mathrm{SD} \\
=2.93) \text { were } \\
\text { recruited at a } \\
\text { large } \\
\text { predominantly } \\
\text { white public } \\
\text { university in } \\
\text { the Midwest. }\end{array}$ & 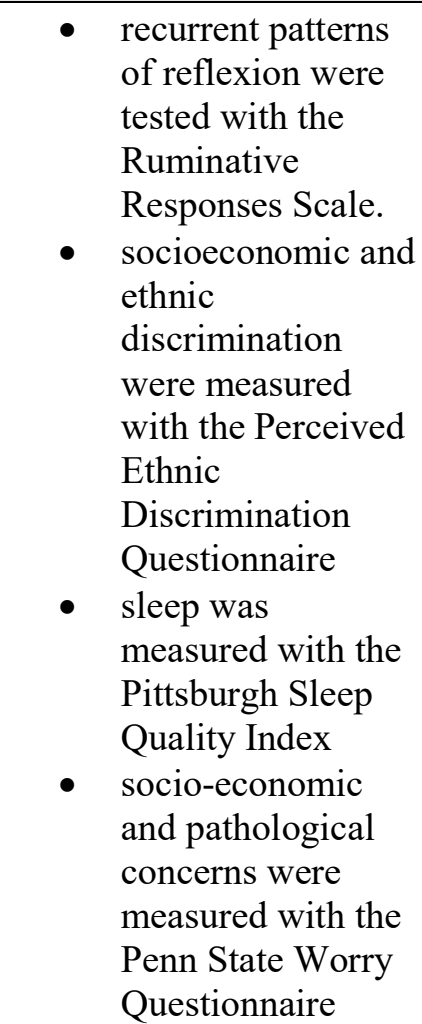 & $\begin{aligned} & \text { negative } \\
& \text { thoughts } \\
&> \text { SES } \\
&> \text { racial } \\
& \text { discrimination } \\
&> \text { quality and } \\
& \text { duration of } \\
& \text { sleep } \\
&> \text { financial } \\
& \text { concern and } \\
& \text { pathological } \\
& \text { concern } \\
&> \text { perseverative } \\
& \text { cognition }\end{aligned}$ & $\begin{array}{l}\text { Ethnic } \\
\text { discrimination } \\
\text { and poor sleep } \\
\text { quality are } \\
\text { strongly } \\
\text { associated with } \\
\text { metabolic and } \\
\text { cardiovascular } \\
\text { diseases, as well } \\
\text { as with mood } \\
\text { disorders. } \\
\text { Addressing } \\
\text { those diseases in } \\
\text { addition to } \\
\text { coping strategies } \\
\text { may reduce } \\
\text { racial disparities } \\
\text { in health. }\end{array}$ \\
\hline $\begin{array}{l}\text { Green et al, } \\
2014^{28}\end{array}$ & $\begin{array}{l}\text { This study } \\
\text { investigated how } \\
\text { the prospective } \\
\text { patterning of } \\
\text { distress over } 20 \\
\text { years was } \\
\text { associated with } \\
\text { insomnia over } \\
\text { that period. }\end{array}$ & $\begin{array}{l}999 \text { respondents } \\
\text { divided in three } \\
\text { cohorts (born } \\
\text { around } 1932, \\
1952 \text {, and 1972) } \\
\text { were followed } \\
\text { for } \\
20 \text { years }\end{array}$ & $\begin{array}{l}\text { - psychiatric distress } \\
\text { was measured } \\
\text { using the General } \\
\text { Health } \\
\text { Questionnaire at } \\
\text { baseline and at 20- } \\
\text { year follow-up. } \\
\text { gender and social } \\
\text { class were assessed } \\
\text { at baseline. } \\
\text { insomnia } \\
\text { symptoms were } \\
\text { assessed every five } \\
\text { years. }\end{array}$ & $\begin{array}{ll}> & \text { insomnia } \\
> & \text { depression } \\
> & \text { anxiety } \\
> & \text { stress } \\
> & \text { social class } \\
> & \text { SES } \\
> & \text { well being } \\
> & \text { psychological } \\
& \text { health } \\
> & \text { sleep habits }\end{array}$ & $\begin{array}{l}\text { sex and } \\
\text { socioeconomic } \\
\text { disparities in } \\
\text { psychiatric } \\
\text { distress are } \\
\text { strongly linked } \\
\text { with disparities } \\
\text { in insomnia } \\
\text { symptoms. }\end{array}$ \\
\hline
\end{tabular}




\begin{tabular}{|c|c|c|c|c|c|}
\hline $\begin{array}{l}\text { Okun et al, } \\
2014^{29}\end{array}$ & $\begin{array}{l}\text { To evaluate the } \\
\text { effect of } \\
\text { socioeconomic } \\
\text { status on } \\
\text { measures of } \\
\text { sleep quality, } \\
\text { continuity, and } \\
\text { quantity in a } \\
\text { large cohort of } \\
\text { pregnant } \\
\text { women. }\end{array}$ & $\begin{array}{l}\text { One hundred } \\
\text { and seventy } \\
\text { pregnant } \\
\text { women at } 10-20 \\
\text { weeks gestation. }\end{array}$ & $\begin{array}{l}\text { - } \text { sleep was assessed } \\
\text { with the Pittsburgh } \\
\text { Sleep Quality } \\
\text { Index and } \\
\text { actigraphy at 10- } \\
\text { 12, 14-16, and 18- } \\
20 \text { weeks gestation. } \\
\text { - SES was defined } \\
\text { by self-reported } \\
\text { annual household } \\
\text { income. } \\
\text { mood disorders } \\
\text { were assessed with } \\
\text { the Inventory for } \\
\text { Depressive } \\
\text { Symptoms } \\
\text { perceived stress } \\
\text { was measured with } \\
\text { The Perceived } \\
\text { Stress Scale }\end{array}$ & 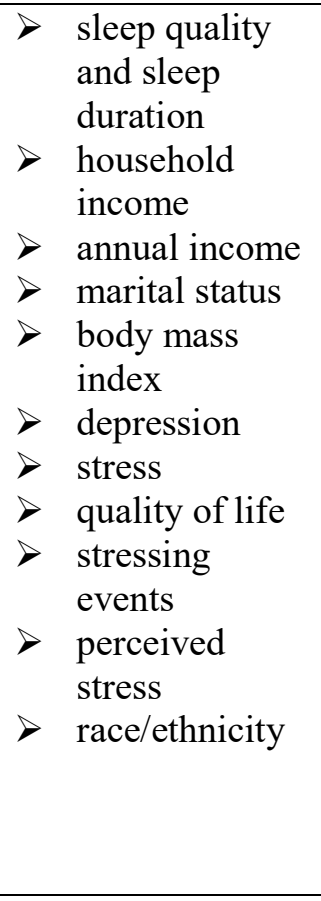 & $\begin{array}{l}\text { Low SES was } \\
\text { associated with } \\
\text { poorer sleep } \\
\text { quality and } \\
\text { fragmented } \\
\text { sleep. Perceived } \\
\text { stress and } \\
\text { financial support } \\
\text { reduce the } \\
\text { associations of } \\
\text { SES with sleep. }\end{array}$ \\
\hline $\begin{array}{l}\text { Chen et al, } \\
2013^{30}\end{array}$ & $\begin{array}{l}\text { To assess the } \\
\text { psychological } \\
\text { and } \\
\text { socioeconomic } \\
\text { health status of } \\
\text { community- } \\
\text { dwelling older } \\
\text { adults in } \\
\text { Taiwan, and to } \\
\text { compare the } \\
\text { psychological } \\
\text { and } \\
\text { socioeconomic } \\
\text { health } \\
\text { inequalities } \\
\text { among people of } \\
\text { different age, } \\
\text { gender, marital } \\
\text { status, and } \\
\text { exercise habits. }\end{array}$ & $\begin{array}{l}384 \text { Taiwanese } \\
\text { community- } \\
\text { dwelling older } \\
\text { adults aged } 65 \\
\text { years old and } \\
\text { more }\end{array}$ & $\begin{array}{l}\text { - } \text { sleep measured } \\
\text { with the Pittsburgh } \\
\text { Sleep Quality } \\
\text { Index } \\
\text { - } \quad \text { financial status } \\
\text { - } \quad \text { social support } \\
\text { - } \text { emotional health } \\
\text { measured with The } \\
\text { Taiwanese } \\
\text { Depression } \\
\text { Questionnaire } \\
\text { the cognitive } \\
\text { functioning } \\
\text { measure with The } \\
\text { Short Portable } \\
\text { Mental Status } \\
\text { Questionnaire } \\
\text { health promotion } \\
\text { behaviors } \\
\text { social engagement }\end{array}$ & $\begin{aligned} &> \text { sleep quality } \\
&> \text { living expenses } \\
&> \text { income } \\
&> \text { level of } \\
& \text { satisfaction } \\
&> \text { duration and } \\
& \text { frequency of } \text { physical } \\
& \text { activity } \\
&> \text { cognition } \\
&> \text { functional } \\
& \text { autonomy } \\
&> \text { lifestyle } \\
&> \text { social } \\
& \text { engagement }\end{aligned}$ & $\begin{array}{l}\text { The major } \\
\text { psychological } \\
\text { and socio- } \\
\text { economic health } \\
\text { concerns were } \\
\text { sleep } \\
\text { disturbances and } \\
\text { financial } \\
\text { burden. } \\
\text { Younger old } \\
\text { adults had better } \\
\text { psychological } \\
\text { and sociological } \\
\text { health. }\end{array}$ \\
\hline
\end{tabular}




\begin{tabular}{|c|c|c|c|c|c|}
\hline $\begin{array}{l}\text { Karlamangla et } \\
\text { al, } 2013^{31}\end{array}$ & $\begin{array}{l}\text { To identify } \\
\text { disparities in the } \\
\text { usual daytime } \\
\text { cortisol rhythm } \\
\text { by age, SES, and } \\
\text { race/ethnicity }\end{array}$ & $\begin{array}{l}\text { A final sample } \\
\text { of } 1693 \\
\text { participants } \\
\text { (from } \\
1409 \text { families) } \\
\text { recruited } \\
\text { through MIDUS } \\
\text { (Midlife in the } \\
\text { United } \\
\text { States Study) } \\
\text { aged } 25 \text { to } 74 \\
\text { years old. }\end{array}$ & $\begin{array}{l}\text { - socio-demographic } \\
\text { and socio- } \\
\text { economic } \\
\text { characteristics } \\
\text { (age, } \\
\text { race / ethnicity, } \\
\text { gender, highest } \\
\text { level of educational } \\
\text { attainment, and } \\
\text { annual household } \\
\text { income) were self- } \\
\text { reported with the } \\
\text { MIDUS } \\
\text { questionnaire } \\
\text { salivary collection } \\
\text { kit to measure } \\
\text { cortisol on waking, } \\
\text { 30 min after } \\
\text { waking, before } \\
\text { lunch and before } \\
\text { bed for seven days } \\
\text { average sleep time } \\
\text { was assessed by } \\
\text { way of the MIDUS } \\
\text { questionnaire } \\
\text { physical and } \\
\text { mental conditions } \\
\text { were assessed by } \\
\text { way of the MIDUS } \\
\text { questionnaire } \\
\end{array}$ & $\begin{array}{ll}> & \text { SES (income, } \\
& \text { occupation, } \\
\text { living area) } & > \\
\text { the daily rate of } \\
\text { cortisol } \\
> & \text { quality and } \\
& \text { duration of } \\
& \text { sleep } \\
> & \text { smoking } \\
> & \text { depression } \\
> & \text { anxiety } \\
> & \text { body mass } \\
& \text { index } \\
> & \text { age } \\
> & \text { sex } \\
> & \text { the ethnic } \\
& \text { group } \\
> & \text { physical } \\
& \text { activity } \\
> & \text { medications } \\
> & \text { cardiovascular } \\
\text { and metabolic } & \text { diseases }\end{array}$ & $\begin{array}{l}\text { Daytime cortisol } \\
\text { levels are higher } \\
\text { in older people } \\
\text { and in men } \\
\text { compared to } \\
\text { women. } \\
\text { Daytime cortisol } \\
\text { rhythm is flatter } \\
\text { in less } \\
\text { privileged social } \\
\text { classes, } \\
\text { confirming that } \\
\text { social stressors } \\
\text { lead to poor } \\
\text { health } \\
\text { outcomes. }\end{array}$ \\
\hline $\begin{array}{l}\text { Stawski et al, } \\
2013^{32}\end{array}$ & $\begin{array}{l}\text { To assess the } \\
\text { daily association } \\
\text { between } \\
\text { recurrent } \\
\text { stressors and } \\
\text { salivary cortisol } \\
\text { levels. }\end{array}$ & $\begin{array}{l}1694 \text { adults } \\
\text { (mean age } 57 \\
\text { years-old, range } \\
33-84 ; 44 \% \\
\text { male) }\end{array}$ & 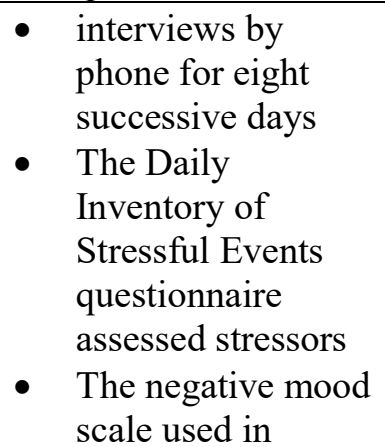 & $\begin{array}{l}\text { elements } \\
\text { causing stress } \\
\text { in the living } \\
\text { environment } \\
\text { (work, family) } \\
>\text { daily cortisol } \\
\text { levels } \\
>\text { negative daily } \\
\text { effect of } \\
\text { stressors }\end{array}$ & $\begin{array}{l}\text { People with } \\
\text { successive } \\
\text { stressful days } \\
\text { show a growing } \\
\text { increase in } \\
\text { cortisol levels } \\
\text { and a decrease } \\
\text { in the quality of } \\
\text { their sleep. }\end{array}$ \\
\hline
\end{tabular}




\begin{tabular}{|c|c|c|c|c|c|}
\hline & & & $\begin{array}{l}\text { MIDUS to measure } \\
\text { the negative effects } \\
\text { of stressors and the } \\
\text { emotions } \\
\text { associated with } \\
\text { them. } \\
\text { a checklist of } 25 \\
\text { physical symptoms } \\
\text { to measure daily } \\
\text { physical symptoms } \\
\text { salivary collection } \\
\text { kit to measure } \\
\text { cortisol on waking, } \\
30 \text { min after } \\
\text { waking, before } \\
\text { lunch and before } \\
\text { bed for four days. } \\
\text { state of sleep }\end{array}$ & $\begin{array}{ll}> & \text { physical } \\
& \text { symptoms } \\
> & \text { emotions }\end{array}$ & \\
\hline $\begin{array}{l}\text { Tom and } \\
\text { Berenson, } 2013^{33}\end{array}$ & $\begin{array}{l}\text { To investigate } \\
\text { the associations } \\
\text { between sleep } \\
\text { quality and } \\
\text { psychosocial } \\
\text { stress with } \\
\text { obesity in } \\
\text { reproductive-age } \\
\text { white, black, and } \\
\text { Hispanic women } \\
\text { of } \\
\text { lower SES. }\end{array}$ & $\begin{array}{l}927 \text { women } \\
\text { aged 16-40 } \\
\text { years }\end{array}$ & $\begin{array}{l}\text { - Sleep was assessed } \\
\text { with the Pittsburgh } \\
\text { Sleep Quality } \\
\text { Index } \\
\text { - SES was measured } \\
\text { by way of } \\
\text { education, } \\
\text { household income, } \\
\text { profession } \\
\text { - mood disorders } \\
\text { were assessed with } \\
\text { the Beck } \\
\text { Depression } \\
\text { Inventory } \\
\text { - perceived stress } \\
\text { was measured with } \\
\text { The Perceived } \\
\text { Stress Scale } \\
\text { - lifestyle } \\
\text { - health habits } \\
\text { obesity }\end{array}$ & $\begin{array}{ll} & \text { sleep quality } \\
> & \text { sleep } \\
& \text { medications } \\
> & \text { sleep latency } \\
> & \text { sleep duration } \\
> & \text { education } \\
> & \text { income } \\
> & \text { profession } \\
> & \text { depression } \\
> & \text { stress levels } \\
> & \text { perceived } \\
& \text { stress } \\
> & \text { body mass } \\
& \text { index } \\
> & \text { weight } \\
> & \text { alcohol } \\
& \text { consumption } \\
> & \text { smoking status } \\
> & \text { physical } \\
& \text { activity } \\
> & \text { race/ethnicity }\end{array}$ & $\begin{array}{l}\text { Even if they } \\
\text { were common in } \\
\text { reproductive- } \\
\text { aged women of } \\
\text { lower SES, poor } \\
\text { sleep quality } \\
\text { and } \\
\text { psychosocial } \\
\text { stressors were } \\
\text { not linked with } \\
\text { variation of } \\
\text { weight. }\end{array}$ \\
\hline
\end{tabular}




\begin{tabular}{|c|c|c|c|c|c|}
\hline $\begin{array}{l}\text { Green et al, } \\
2012^{34}\end{array}$ & $\begin{array}{l}\text { To describe } \\
\text { longitudinal } \\
\text { patterns of } \\
\text { insomnia } \\
\text { symptoms as } \\
\text { people age and } \\
\text { examines how } \\
\text { they vary } \\
\text { according to } \\
\text { gender } \\
\text { and profession. }\end{array}$ & $\begin{array}{l}\text { One cohort } \\
\text { approximately } \\
36-57 \text { years of } \\
\text { age at baseline } \\
(\mathrm{n}=1,444) \text {, and } \\
\text { another aging } \\
\text { from } 56-76 \\
\text { years }(\mathrm{n}= \\
1,551) .\end{array}$ & $\begin{array}{l}\text { - sleep latency and } \\
\text { the ability to stay } \\
\text { asleep were } \\
\text { measured with the } \\
\text { Pittsburgh Sleep } \\
\text { Quality Index } \\
\text { - SES was measured } \\
\text { with the household } \\
\text { reference rank that } \\
\text { takes into account } \\
\text { the highest } \\
\text { profession of the } \\
\text { couple and material } \\
\text { resources } \\
\text { three cohorts of } \\
\text { different times of } \\
\text { birth (1932, } 1952 \\
\text { and } 1972) \text { were } \\
\text { followed for } 20 \\
\text { years with four } \\
\text { interviews } \\
\text { (1987/1988, } \\
1990 / 1992, \\
1995 / 1997, \\
2000 / 2004, \\
2007 / 2008)\end{array}$ & $\begin{array}{ll}> & \text { quality of sleep } \\
> & \text { SES } \\
> & \text { sex } \\
> & \text { age }\end{array}$ & $\begin{array}{l}\text { Chronic } \\
\text { symptoms } \\
\text { expressed by } \\
\text { difficulties in } \\
\text { maintaining and } \\
\text { initiating sleep } \\
\text { are influenced } \\
\text { by social } \\
\text { factors. }\end{array}$ \\
\hline $\begin{array}{l}\text { Lo and Lee, } \\
2012^{35}\end{array}$ & $\begin{array}{l}\text { To explore sleep } \\
\text { disorders among } \\
\text { seniors by } \\
\text { investigating the } \\
\text { prevalence of } \\
\text { poor sleep } \\
\text { quality, the } \\
\text { relationship } \\
\text { between sleep } \\
\text { quality and } \\
\text { health-related } \\
\text { quality of life, } \\
\text { and associated } \\
\text { factors of good } \\
\text { sleepers in }\end{array}$ & $\begin{array}{l}\text { Older } \\
\text { community- } \\
\text { dwelling } \\
\text { individuals }(\mathrm{n}= \\
\text { 301) aged } 60 \\
\text { years and more. }\end{array}$ & $\begin{array}{l}\text { - a validated } \\
\text { questionnaire } \\
\text { collected } \\
\text { socioeconomics } \\
\text { and } \\
\text { sociodemographic } \\
\text { data } \\
\text { - the state and } \\
\text { quality of sleep are } \\
\text { measured with the } \\
\text { Pittsburgh Sleep } \\
\text { Quality Index } \\
\text { Quality of life is } \\
\text { measured with the }\end{array}$ & $\begin{array}{l}\text { sleep (quality, } \\
\text { duration, } \\
\text { number of } \\
\text { awakenings, } \\
\text { depth) } \\
\text { demographic } \\
\text { variables (age, } \\
\text { gender, } \\
\text { occupation, } \\
\text { level of } \\
\text { education, } \\
\text { marital status, } \\
\text { income, area } \\
\text { and type of } \\
\text { dwelling) }\end{array}$ & $\begin{array}{l}\text { There is a strong } \\
\text { negative } \\
\text { association } \\
\text { between poor } \\
\text { quality and } \\
\text { short-term sleep } \\
\text { with a healthy } \\
\text { quality of life, } \\
\text { and it worsens } \\
\text { with aging. }\end{array}$ \\
\hline
\end{tabular}




\begin{tabular}{|c|c|c|c|c|c|}
\hline & $\begin{array}{l}\text { different age } \\
\text { groups. }\end{array}$ & & $\begin{array}{l}\text { Medical Outcomes } \\
\text { Study 36-item } \\
\text { Short Form Health } \\
\text { Survey. }\end{array}$ & $\begin{array}{l}\text { state of health } \\
\text { related to } \\
\text { quality of life }\end{array}$ & \\
\hline $\begin{array}{l}\text { Gureje et al, } \\
2011^{36}\end{array}$ & $\begin{array}{l}\text { To determine the } \\
\text { incidence and } \\
\text { risk factors for } \\
\text { insomnia in a } \\
\text { population of } \\
\text { older people in } \\
\text { sub-Saharan } \\
\text { Africa. }\end{array}$ & $\begin{array}{l}\text { A cohort of } \\
\text { community- } \\
\text { dwelling } 1307 \\
\text { seniors, aged } 65 \\
\text { years old and } \\
\text { over, followed } \\
\text { for } 1 \text { year }\end{array}$ & $\begin{array}{l}\text { insomnia and } \\
\text { depression were } \\
\text { measured with } \\
\text { version } 3 \text { of the } \\
\text { Composite } \\
\text { International } \\
\text { Diagnostic } \\
\text { Interview } \\
\text { Dementia was } \\
\text { measured with the } \\
\text { 10-Word Delayed } \\
\text { Recall Test, which } \\
\text { is a memory test } \\
\text { Functional capacity } \\
\text { was measured with } \\
\text { the Clinician } \\
\text { Home-based } \\
\text { Interview, which is } \\
\text { a } 10 \text {-item } \\
\text { questionnaire } \\
\text { measuring the } \\
\text { cognitive function } \\
\text { of the senior and } \\
\text { his knowledge of } \\
\text { daily basic tasks to } \\
\text { be performed. } \\
\text { the stressful events } \\
\text { of the last } 12 \\
\text { months that require } \\
\text { social support and / } \\
\text { or caregivers, were } \\
\text { measured with the } \\
\text { List of Threatening } \\
\text { Experiences } \\
\text { SES was measured } \\
\text { by evaluating the } \\
\text { neighborhood / } \\
\end{array}$ & $\begin{aligned} & \text { Insomnia } \\
&> \text { SES } \\
& \text { autonomy and } \\
& \text { lifestyle } \\
& \text { anxious and } \\
& \text { depressive } \\
& \text { syndromes } \\
&> \text { dementia } \\
&> \text { the stressful } \\
& \text { events of the } \\
& \text { last } 12 \text { months } \\
&> \text { the temporal } \\
& \text { evolution of } \\
& \text { the association } \\
& \text { between } \\
& \text { stressful events } \\
& \text { and symptoms } \text { of insomnia } \\
&> \text { the general } \\
& \text { physical state } \text { (body mass } \\
& \text { index, } \\
& \text { cardiovascular } \\
& \text { diseases) } \\
& \text { comorbidities }\end{aligned}$ & $\begin{array}{l}\text { Incidence and } \\
\text { chronicity of } \\
\text { insomnia are } \\
\text { higher in older } \\
\text { people. } \\
\text { Individuals with } \\
\text { chronic health } \\
\text { conditions have } \\
\text { higher risk of } \\
\text { persistent } \\
\text { insomnia. }\end{array}$ \\
\hline
\end{tabular}




\begin{tabular}{|c|c|c|c|c|c|}
\hline & & & $\begin{array}{l}\text { type of house and } \\
\text { its contents }\end{array}$ & & \\
\hline $\begin{array}{l}\text { Hawkley et al, } \\
2011^{37}\end{array}$ & $\begin{array}{l}\text { To investigate } \\
\text { implications of } \\
\text { SES over } \\
\text { physiological } \\
\text { dysregulation. }\end{array}$ & $\begin{array}{l}\text { A population- } \\
\text { based study of } \\
229 \text { older adults } \\
\text { (age range 51- } \\
69 \text { years old) }\end{array}$ & $\begin{array}{l}\text { - Allostatic Load } \\
\text { was computed } \\
\text { from } 9 \text { markers } \\
\text { encompassing } \\
\text { cardiovascular } \\
\text { system } \\
\text { functioning, } \\
\text { sympathetic } \\
\text { nervous and } \\
\text { adrenomedullary } \\
\text { system functioning } \\
\text { central obesity } \\
\text { (waist } \\
\text { circumference) } \\
\text { hypothalamic- } \\
\text { pituitary-adrenal } \\
\text { axis functioning } \\
\text { (cortisol) } \\
\text { risk factors for } \\
\text { development of } \\
\text { atherosclerosis } \\
\text { (high density } \\
\text { lipoprotein and } \\
\text { total cholesterol), } \\
\text { and glucose } \\
\text { metabolism } \\
\text { (glycated } \\
\text { hemoglobin) } \\
\text { chronic health } \\
\text { conditions } \\
\text { measured with } \\
\text { validated } \\
\text { questionnaires } \\
\text { psychosocial and } \\
\text { personality } \\
\text { variables } \\
\text { sleep } \\
\text { lifestyle } \\
\text { - }\end{array}$ & $\begin{array}{ll}> & \text { sleep (quality } \\
& \text { and duration) } \\
> & \text { allostatic load } \\
> & \text { stress } \\
> & \text { social network } \\
> & \text { health } \\
& \text { behaviors } \\
> & \text { coping style } \\
> & \text { well-being } \\
> & \text { depression } \\
> & \text { emotional } \\
& \text { stability } \\
> & \text { spirituality } \\
> & \text { education } \\
> & \text { household } \\
> & \text { income } \\
> & \text { neighborhood } \\
> & \text { ethnicity } \\
> & \text { social support } \\
> & \text { alcoholism } \\
> & \text { smoking } \\
> & \text { nutritional } \\
& \text { habits }\end{array}$ & $\begin{array}{l}\text { The effects of } \\
\text { SES are specific } \\
\text { to certain } \\
\text { systems in a } \\
\text { middle to early } \\
\text { old-age } \\
\text { population, } \\
\text { creating and } \\
\text { worsening the } \\
\text { association } \\
\text { between } \\
\text { allostatic load } \\
\text { and sleep } \\
\text { disturbances. }\end{array}$ \\
\hline
\end{tabular}




\begin{tabular}{|c|c|c|c|c|c|}
\hline & & & - $\quad$ SES & & \\
\hline $\begin{array}{l}\text { Goodin et al, } \\
2010^{38}\end{array}$ & $\begin{array}{l}\text { To investigate } \\
\text { the relation } \\
\text { between } \\
\text { perceived social } \\
\text { status and } \\
\text { subjective sleep } \\
\text { quality. }\end{array}$ & $\begin{array}{l}149 \text { college } \\
\text { students }\end{array}$ & $\begin{array}{ll}\text { - } & \text { sociodemographic } \\
\text { data collected with } \\
\text { homemade } \\
\text { questionnaire } \\
\text { - Sleep } \\
\text { - } \quad \text { SES } \\
\text { - ethnicity } \\
\text { - } \text { health conditions }\end{array}$ & $\begin{array}{ll}> & \text { sleep quality } \\
> & \text { social class } \\
> & \text { race } \\
> & \text { quality of life } \\
> & \text { perceived SES }\end{array}$ & $\begin{array}{l}\text { A low perceived } \\
\text { social status has } \\
\text { a negative } \\
\text { influence on } \\
\text { sleep quality for } \\
\text { African and } \\
\text { Asian } \\
\text { Americans. }\end{array}$ \\
\hline $\begin{array}{l}\text { Kumari et al, } \\
2010^{39}\end{array}$ & $\begin{array}{l}\text { To investigate if } \\
\text { dysregulation of } \\
\text { the } \\
\text { hypothalamic- } \\
\text { pituitary-adrenal } \\
\text { axis associated } \\
\text { with } \\
\text { disadvantaged } \\
\text { social position in } \\
\text { working } \\
\text { populations also } \\
\text { occurs in retired } \\
\text { old people. }\end{array}$ & $\begin{array}{l}3992 \\
\text { participants } \\
\text { (mean age } 61 \\
\text { years; range } 50- \\
74 \\
\text { years) from the } \\
\text { Whitehall II } \\
\text { Study }\end{array}$ & $\begin{array}{l}\text { - } \text { salivary rate of } \\
\text { cortisol measured } \\
\text { six times per day } \\
\text { (at waking, } 30 \\
\text { minutes, } 2.5 \text { hours, } \\
8 \text { hours, } 12 \text { hours, } \\
\text { and bedtime) with } \\
\text { a commercial } \\
\text { immunoassay with } \\
\text { chemiluminescence } \\
\text { detection } \\
\text { social position } \\
\text { assessed by way of } \\
\text { the MacArthur } \\
\text { subjective social } \\
\text { position scale } \\
\text { health behaviors } \\
\text { - } \text { sleep habits } \\
\text { mood disorders } \\
\text { assessed by way of } \\
\text { The Center for } \\
\text { Epidemiologic } \\
\text { Studies Depression } \\
\text { Scale } \\
\text { body mass index } \\
\text { stress }\end{array}$ & $\begin{aligned} & \text { cortisol } \\
> & \text { awakening } \\
& \text { response } \\
> & \text { sleep behaviors } \\
& \text { (waking up } \\
& \text { time, insomnia, } \\
& \text { sleep duration) } \\
> & \text { smoking status } \\
> & \text { diet/nutrition } \\
> & \text { age } \\
> & \text { sex } \\
> & \text { SES (social } \\
& \text { position, } \\
& \text { education, } \\
& \text { income) } \\
> & \text { depression } \\
> & \text { blood pressure } \\
> & \text { height } \\
> & \text { weight } \\
> & \text { daily level of } \\
& \text { stress }\end{aligned}$ & $\begin{array}{l}\text { In men, poorer } \\
\text { health, sleep } \\
\text { behaviors } \\
\text { and unstable } \\
\text { income mediate } \\
\text { the effect of } \\
\text { occupational } \\
\text { status and } \\
\text { wealth on } \\
\text { cortisol } \\
\text { secretion }\end{array}$ \\
\hline $\begin{array}{l}\text { Phelan et al, } \\
2010^{40}\end{array}$ & $\begin{array}{l}\text { To review how } \\
\text { social conditions } \\
\text { and their } \\
\text { determinants } \\
\text { affect global }\end{array}$ & $\begin{array}{l}\text { Population- } \\
\text { based study. }\end{array}$ & $\begin{array}{l}\text { - Narrative review of } \\
\text { literature }\end{array}$ & $\begin{array}{ll}> & \text { health status } \\
> & \text { social class } \\
> & \text { SES } \\
> & \text { health policies }\end{array}$ & $\begin{array}{l}\text { Without more } \\
\text { programs of } \\
\text { social } \\
\text { management of } \\
\text { resources or }\end{array}$ \\
\hline
\end{tabular}




\begin{tabular}{|c|c|c|c|c|c|}
\hline & $\begin{array}{l}\text { health in the life } \\
\text { course. }\end{array}$ & & & $\begin{array}{l}\text { consequences } \\
\text { of social } \\
\text { inequalities } \\
\text { theory on } \\
\text { correlations } \\
\text { between social } \\
\text { conditions and } \\
\text { trajectory of } \\
\text { health }\end{array}$ & $\begin{array}{l}\text { evaluation of the } \\
\text { development of } \\
\text { socioeconomic } \\
\text { disparities } \\
\text { among sick } \\
\text { people, many } \\
\text { health issues } \\
\text { will occur and } \\
\text { be costly to } \\
\text { citizens. }\end{array}$ \\
\hline $\begin{array}{l}\text { Tomfohr et al, } \\
2010^{41}\end{array}$ & $\begin{array}{l}\text { To measure the } \\
\text { association } \\
\text { between SES in } \\
\text { childhood and } \\
\text { adult sleep, to } \\
\text { analyze adult } \\
\text { sleep according } \\
\text { to race, and } \\
\text { whether } \\
\text { associations } \\
\text { between SES, } \\
\text { race and sleep } \\
\text { are influenced } \\
\text { by factors such } \\
\text { as health } \\
\text { practices and } \\
\text { current social } \\
\text { status. }\end{array}$ & $\begin{array}{l}128 \text { Black and } \\
\text { White Adults }\end{array}$ & 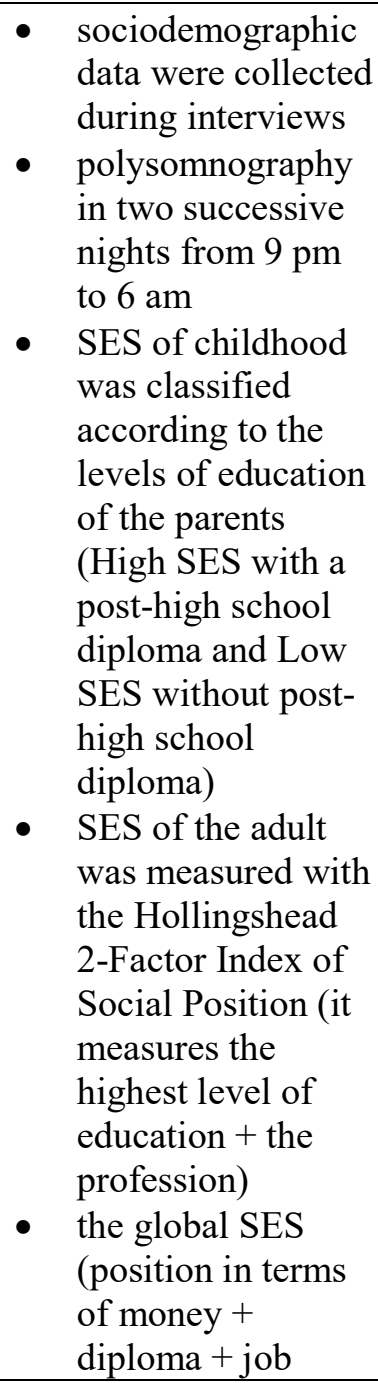 & $\begin{array}{ll}> & \text { SES } \\
\text { the low SES } & \text { and the high } \\
& \text { SES } \\
\text { clinical } \\
\text { parameters of } \\
\text { sleep ((slow- } \\
\text { wave) } \\
>\text { the quality of } \\
\text { sleep } \\
>\text { daytime } \\
\text { sleepiness } \\
>\text { physical } \\
\text { activity } \\
>\text { the social class } \\
>\text { the habits of } \\
\text { life } \\
>\text { socio- } \\
\text { demographic } \\
\text { data (age, sex, } \\
\text { years of } \\
\text { education, skin } \\
\text { color, income, } \\
\text { occupation, } \\
\text { body mass } \\
\text { index) }\end{array}$ & $\begin{array}{l}\text { Participants with } \\
\text { lower childhood } \\
\text { SES spent more } \\
\text { time in Stage } 2 \\
\text { sleep and less } \\
\text { time in slow- } \\
\text { wave sleep than } \\
\text { those with } \\
\text { higher } \\
\text { childhood } \\
\text { SES. Women } \\
\text { from low } \\
\text { childhood SES } \\
\text { had more } \\
\text { difficulties to } \\
\text { fall asleep } \\
\text { compared with } \\
\text { women with } \\
\text { high SES. Black } \\
\text { participants } \\
\text { spent less time } \\
\text { in slow-wave } \\
\text { sleep than } \\
\text { White. An } \\
\text { interaction Age } \\
\text { X Race was } \\
\text { identified in the } \\
\text { prediction of } \\
\text { subjective sleep } \\
\text { quality. }\end{array}$ \\
\hline
\end{tabular}




\begin{tabular}{|c|c|c|c|c|c|}
\hline & & & $\begin{array}{l}\text { respected in the } \\
\text { USA) was } \\
\text { measured with the } \\
\text { MacArthur Scale } \\
\text { - quality of sleep } \\
\text { was measured by } \\
\text { way of the } \\
\text { Pittsburgh Sleep } \\
\text { Quality Index } \\
\text { daytime sleepiness } \\
\text { was measured by } \\
\text { way of the } \\
\text { Epworth } \\
\text { Sleepiness Scale } \\
\text { health practices } \\
\text { (alcoholism, } \\
\text { smoking) were } \\
\text { self-reported and } \\
\text { physical activity } \\
\text { was measured by } \\
\text { way of the Leisure } \\
\text { Time Exercise } \\
\text { Questionnaire }\end{array}$ & & \\
\hline $\begin{array}{l}\text { Friedman et al, } \\
2007^{42}\end{array}$ & $\begin{array}{l}\text { To test the } \\
\text { hypothesis that } \\
\text { SES would be } \\
\text { associated with } \\
\text { objectively } \\
\text { measured sleep } \\
\text { quality, even } \\
\text { after controlling } \\
\text { for related } \\
\text { covariates } \\
\text { (health status, } \\
\text { psychosocial } \\
\text { features). }\end{array}$ & $\begin{array}{l}94 \text { women, } 61 \\
\text { to } 90 \text { years of } \\
\text { age }\end{array}$ & $\begin{array}{l}\text { - SES is determined } \\
\text { with pre-tax } \\
\text { household income } \\
\text { sleep quality is } \\
\text { measured with the } \\
\text { Night Cap Sleep } \\
\text { System + } \\
\text { Pittsburgh Sleep } \\
\text { Quality Index } \\
\text { - the state of health } \\
\text { is estimated with } \\
\text { the objective } \\
\text { measures of } \\
\text { medical records } \\
\text { depression is } \\
\text { measured with the } \\
\text { Center for }\end{array}$ & $\begin{aligned}> & \text { SES } \\
> & \text { health } \\
> & \text { quality of sleep } \\
> & \text { depressive } \\
& \text { syndromes } \\
> & \text { neuroticism } \\
> & \text { lifestyle habits } \\
& \text { (smoking, } \\
& \text { alcoholism, } \\
& \text { caffeine) }\end{aligned}$ & $\begin{array}{l}\text { There are } \\
\text { behavioral and } \\
\text { biological } \\
\text { implications of } \\
\text { social ladder } \\
\text { and sleep } \\
\text { quality in health } \\
\text { processes, and a } \\
\text { negative } \\
\text { association } \\
\text { exists among } \\
\text { sleep disorders, } \\
\text { low SES and } \\
\text { chronic } \\
\text { morbidities. }\end{array}$ \\
\hline
\end{tabular}




\begin{tabular}{|c|c|c|c|c|c|}
\hline & & & $\begin{array}{l}\text { Epidemiology } \\
\text { Disease Scale } \\
\text { - Neuroticism is } \\
\text { measured with a } \\
\text { subscale of the } \\
\text { NEO personality } \\
\text { inventory }\end{array}$ & & \\
\hline $\begin{array}{l}\text { Adler et al, } \\
2000^{43}\end{array}$ & $\begin{array}{l}\text { Associations } \\
\text { between } \\
\text { objective and } \\
\text { subjective SES } \\
\text { were compared } \\
\text { with } \\
\text { psychological } \\
\text { and physical } \\
\text { variables. }\end{array}$ & $\begin{array}{l}157 \text { healthy } \\
\text { white women }\end{array}$ & $\begin{array}{l}\text { - } \text { social status } \\
\text { measured by the } \\
\text { subjective SES } \\
\text { scale. } \\
\text { sleep measured } \\
\text { with the Pittsburgh } \\
\text { Sleep Quality } \\
\text { Index } \\
\text { biological } \\
\text { measures were } \\
\text { performed in a } \\
\text { laboratory } \\
\text { psychological } \\
\text { variables were } \\
\text { measured with the } \\
\text { Perceived Stress } \\
\text { Scale }+ \text { the } \\
\text { Negative Affect } \\
\text { subscale of the } \\
\text { Positive and } \\
\text { Negative } \\
\text { Affectivity Scale }+ \\
\text { the Life } \\
\text { Orientation Test }+ \\
\text { the Coping } \\
\text { Orientation to } \\
\text { Problems } \\
\text { Experienced }\end{array}$ & 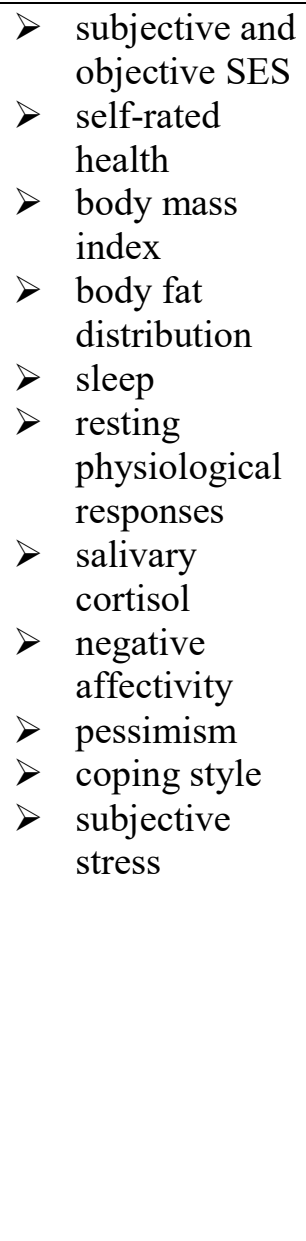 & $\begin{array}{l}\text { Psychological } \\
\text { perceptions of } \\
\text { lower social } \\
\text { status contribute } \\
\text { to the SES- } \\
\text { health gradient } \\
\text { and have } \\
\text { significant } \\
\text { relationships } \\
\text { with stress, } \\
\text { sleep disorders } \\
\text { and metabolic } \\
\text { diseases. }\end{array}$ \\
\hline $\begin{array}{l}\text { Bromberger and } \\
\text { Matthews, } \\
1999^{44}\end{array}$ & $\begin{array}{l}\text { The authors } \\
\text { focused on the } \\
\text { first piece of the } \\
\text { stress-sleep- } \\
\text { health }\end{array}$ & $\begin{array}{l}\text { a local cohort of } \\
462 \text { women } \\
\text { from the } \\
\text { multisite Study } \\
\text { of Women's }\end{array}$ & $\begin{array}{ll}\text { - } & \text { data were collected } \\
\text { from SWAN study } \\
\text { - } & \text { SES was analyzed } \\
\text { - } & \text { sleep components } \\
\text { were analyzed }\end{array}$ & $\begin{array}{ll}> & \text { income } \\
> & \text { education } \\
> & \text { health } \\
& \text { conditions }\end{array}$ & $\begin{array}{l}\text { poverty is } \\
\text { associated with } \\
\text { subjective sleep } \\
\text { complaints in } \\
\text { middle-aged }\end{array}$ \\
\hline
\end{tabular}




\begin{tabular}{|c|c|c|c|c|c|}
\hline & $\begin{array}{l}\text { relationship, that } \\
\text { is, the impact of } \\
\text { the chronic } \\
\text { stress of lower } \\
\text { SES on } \\
\text { subjective sleep } \\
\text { complaints }\end{array}$ & $\begin{array}{l}\text { Health Across } \\
\text { the Nation } \\
\text { (SWAN). Age } \\
\text { range was } 41-52 \\
\text { years, } 35 \% \text { were } \\
\text { African- } \\
\text { American and } \\
\text { the remainder } \\
\text { were Caucasian }\end{array}$ & $\begin{array}{l}\text { - level of stress was } \\
\text { computed } \\
\text { - } \quad \text { ethnicity }\end{array}$ & $\begin{aligned} & \text { sleep } \\
& \text { difficulties } \\
& \text { (insomnia, } \\
& \text { difficulty } \\
& \text { falling asleep) } \\
> & \text { chronic stress } \\
> & \text { ethnicity } \\
> & \text { SES }\end{aligned}$ & $\begin{array}{l}\text { women, } \\
\text { irrespective of } \\
\text { age, race and } \\
\text { education. } \\
\text { Chronic stress } \\
\text { associated with } \\
\text { lower SES } \\
\text { mediate the } \\
\text { association of } \\
\text { poverty with } \\
\text { poor sleep. }\end{array}$ \\
\hline $\begin{array}{l}\text { Van Cauter and } \\
\text { Spiegel, } 1999^{45}\end{array}$ & $\begin{array}{l}\text { This article } \\
\text { discusses the } \\
\text { hypothesis that } \\
\text { the adverse } \\
\text { impact of low } \\
\text { SES on health } \\
\text { may be partly } \\
\text { mediated by } \\
\text { decrements in } \\
\text { sleep duration } \\
\text { and quality. }\end{array}$ & $\begin{array}{l}\text { Young and } \\
\text { healthy adults }\end{array}$ & $\begin{array}{l}\text { Division into two } \\
\text { groups: strong SES } \\
\text { and weak SES } \\
\text { Blood test of } \\
\text { cortisol, glucose, } \\
\text { insulin, markers of } \\
\text { orthosympathetic } \\
\text { and } \\
\text { parasympathetic } \\
\text { electrical activity } \\
\text { Sleep was } \\
\text { measured with a } \\
\text { mixed method of } \\
\text { night-time sleep } \\
\text { system + EEG }+ \\
\text { monitoring of brain } \\
\text { waves + the } \\
\text { Pittsburgh Sleep } \\
\text { Quality Index + the } \\
\text { Karolinska } \\
\text { somnolence scale } \\
\end{array}$ & $\begin{aligned}> & \text { carbohydrates } \\
> & \text { metabolism } \\
> & \text { endocrine } \\
& \text { function } \\
> & \text { sympatho- } \\
& \text { vagal balance } \\
> & \text { cortisol } \\
> & \text { glucose } \\
> & \text { insulin } \\
> & \text { inhibitory / } \\
& \text { excitatory } \\
& \text { electrical } \\
& \text { activity }\end{aligned}$ & $\begin{array}{l}\text { Chronic sleep } \\
\text { debt caused by } \\
\text { low SES is } \\
\text { partially } \\
\text { associated with } \\
\text { metabolic } \\
\text { diseases that } \\
\text { increase } \\
\text { comorbidity. }\end{array}$ \\
\hline
\end{tabular}

Table 1: Details of studies included in the results 


\section{RESULTS}

\section{Relation between allostatic load and sleep}

Experiences from our environment stimulate our perception and our training capabilities. These training capabilities are improved by quality and length of our sleep ${ }^{46,47}$. Recent results showed that repetitive stimuli trigger cortical neurons and their mechanisms of synaptic plasticity, mediating training and consolidation during sleep ${ }^{12,13}$. SD such as insomnia, narcolepsy and sleepwalking are frequently associated with cognitive impairment, both in healthy people and in those with neurological disorders such as parkinsonian syndromes or $\mathrm{MD}^{48,49}$. Such SD may result from MD or neurodegenerative diseases at an early stage, and may be the initial manifestations of neuropsychiatric syndromes 17,18,50. Insomnia (e.g. frequent and early alarm clocks, difficulty sustaining sleep) and excessive diurnal somnolence (e.g. attacks of sleep, frequent drowsiness lasting the day) are important examples of disordered brain function and may have several different causes like some forms of parkinsonism, medications and psychiatric disorders ${ }^{6,51}$.

Stress is an important feature associated with SD. Environmental stress results from exposure to multiple environmental stressors (e.g. housing, income, social relationships) and varies according to SES, and needs to be distinguished from psychological stress in the development of MD such as anxiety and depression ${ }^{15,52-54}$. In older people, the level of exposure to environmental stressors influences psychological stress. Thus, development of SD may be affected by several external factors (environmental and socioeconomic) and biological factors (hormones, circadian cycle, practices of life, medical history, medication) ${ }^{6,15,51-54}$. 
Current literature describes the rise of psychological, environmental and socioeconomic factors in several populations ${ }^{55,56}$. The combined interaction of socioeconomic and psychobiological factors over SD has not been studied in depth. As much as the prevalence of SD is higher in the population over 50 years-old, these issues have not been addressed in much depth in younger adults. Current epidemiological data also show higher incidence of neurological diseases and mental illness for elders, compared to adults under 40 years-old ${ }^{54,57}$. It is important to understand the simultaneous effects of environmental stimuli and psychological profiles on the evolution of SD according to different age ranges, because stressors are the same and probably start to affect people at an early age. The allostatic load is a manifestation of this long exposure to stress, and people in the same community are affected differently even with the same stressors ${ }^{58-60}$.

\section{Relation between socioeconomic status, sleep and mood disorders}

As is the case with any biological feature, health status is highly variable for any person in a given population. Certain individuals die at a very early age; others have chronic diseases, and many live up until a very advanced age. Health differences may be analyzed according to geographic region, race, age ranges, and according to SES ${ }^{60,61}$. These factors reveal systematic trends in the distribution of health so that, from birth, each person is not as likely as the other to live in good health for a long time. The SES indicates the position that a person holds in the community. One cannot measure this status directly, but there are some indirect indicators, for example, income, education, occupation, household or the social class (SC) ${ }^{60,61}$. Whatever the indicator used, there is a universal tendency for people from lower socioeconomic groups to die younger and to get sick more often during their lives. The concept of "socioeconomic groups" is identical to the term "socioeconomic category". A socioeconomic category is generally defined as a class in which members of a community or a population have similar features in common, such as professional indicators, age, sex, social position, income, education, environmental stress and psychological stressors ${ }^{61}$. 
Social position and economic disparity are strong predictors of health inequalities. Exposure to low income, low levels of education and precarious employment status may impair indicators of health in a population by way of several indirect mechanisms that limit access to better lifestyles and proper healthcare ${ }^{23,60,62}$.

Predisposing risk factors are recurring elements that increase the odds of development of a disease, usually present in the environment or being part of the lifestyle ${ }^{61,63}$. Such risk factors may be environmental, ${ }^{63}$ biological and psychosocial ${ }^{62,64,65}$. Among biopsychosocial risk factors we have metabolic heredity, tobacco addiction, sedentarism, and diseases such as diabetes mellitus, obesity, arterial hypertension, hypercholesterolemia, and stress ${ }^{1,20,66}$. Arterial hypertension is the most important risk factor for stroke, whereas environmental and psychological stress are major psychosocial risk factors for MD (depression and anxiety) and SD such as insomnia. When several risk factors are present, the risk may result from the product of them rather than the sum.

Certain risk factors (genetic or environmental) or unforeseen events in our daily lives often escape our control. There is a pressing need for more research on prevention, pharmacological therapy and rehabilitation of patients with SD. SD are usually progressive and strongly correlated with living conditions ${ }^{53}$. SES is considered in the diagnosis and in the response to therapy of SD by way of psychological stress, which is a mediator of environmental stress ${ }^{67,68}$.

In older people, the level of exposure to the environmental stressors exerts an influence on psychological stress ${ }^{54,69}$. There is a strong relation between environmental stress and $\mathrm{SD}$, but also between environmental stress and MD such as depression and anxiety ${ }^{2,25}$. A similar relation would also exist between stress and cognition, more importantly for young adults. Young adults are more prone to psychological stressors, therefore prone to MD and cognitive disorders, incidentally more frequent in people under 40 years ${ }^{20,70}$. MD usually impair academic performance, social and professional relationships. 
Psychological stress, moderated by MD, would be a mediator of the effect of environmental stress over SD, which can become chronic $^{25,26,59,71-73}$. Physical and emotional balance are required for proper functionality. Manifestations of stress are associated with the appearance or aggravation of MD and SD ${ }^{74,75}$. Psychological stress induced by some professional (for example night shift work, building jobs, customer relations) or academic environments (for example graduated studies, medical school) results in a combination of risk factors which worsen cognitive impairments and SD ${ }^{18,50,76}$. The risk of cognitive impairment is more important for people who have difficulty to fall asleep. People with cognitive disorders often have reduced length of sleep, but also difficulty falling asleep, cardiovascular and respiratory dysfunction, and neurological impairment including memory dysfunction ${ }^{17}$. Cognitive disorders may also worsen when neuropsychiatric conditions are present (anxiety, depression, general discomfort) and result in light sleep disturbances ${ }^{9,10}$. Overall, cognitive decline is accelerated when there is a disturbance of the quality and the duration of sleep. MD probably play a central role in the cognition of young adults who, however, do not have as many comorbidities or diagnoses of neurodegenerative diseases as older people; and reduced psychological stress will, hypothetically, lead to decreased incidence or aggravation of cognitive disorders ${ }^{1,17,18}$. Improved living conditions (including professional environments, psychosocial and financial support) would reduce the devastating effects of stress on cognition. In this context, SD would be indicators of cognitive decline well before the diagnoses of depression and anxiety ${ }^{77,78}$. In the current state of knowledge and scientific findings, the most recurrent psychological and social stressors related to sleep disturbances are the following: ethnicity, well-being, households, obesity, social ties and support, discrimination, education, low-SC or low-incomes and multiple comorbidities $1,15,16,20,40,55,63,67,79$. Overall, the risk of SD increases when an individual has a lower SES, one or multiple comorbidities (like obesity and mood disorders), and is exposed to permanent stressors (i.e. discrimination, lack of social support, low income) in his environment leading to allostatic load. In the same logic, an individual living in relatively good conditions (i.e. healthy habits, no chronic diseases) with a satisfactory income (middle 
and higher SES) and very little stress in his environment has a small risk of SD in his lifetime (except when induced by physiological dysfunctions). Figure 2 summarizes these interactions, with their influences one by one or in association with sleep.

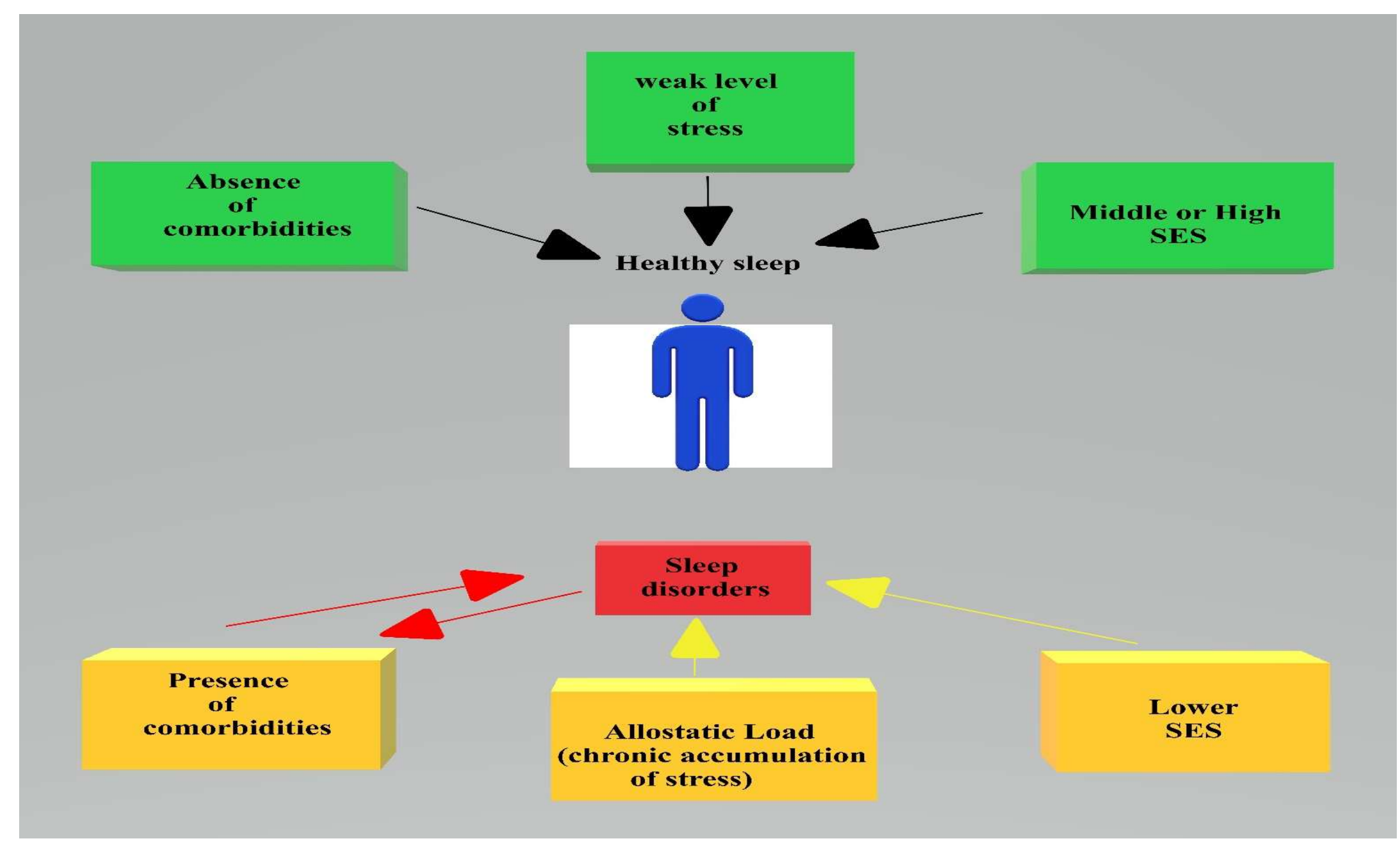

Fig. 2: Theoretical relation between comorbidities, Socioeconomic status (SES) and stress. 


\section{Relation between socioeconomic status and circadian rhythms}

CRs are $24 \mathrm{~h}$ cycles in physiology and behaviour that are driven by an internal molecular clock. The molecular mechanism underlying this rhythm is the cell autonomous transcription-translation feedback loop (TTFL). In mammals, the transcription factors CLOCK and BMAL1 drive the expression of Period (Per1/2) and Cryptochrome (Cry1/2), whose protein products repress the function of CLOCK and BMAL1 ${ }^{80}$. CLOCK and BMAL1 bind to DNA elements known as E-boxes that lie within the promoters of about $1 / 3$ of the genome, which as result, can oscillate with a $24 \mathrm{~h}$ rhythm to regulate tissue-specific metabolic and physiological functions. This molecular clock exists within most cells of the body, which are maintained in synchrony by a master pacemaker, the $\mathrm{SCN}$, residing within the hypothalamus. The SCN receives direct input on the environmental light dark cycle from the retinohypothalamic tract, thus ensuring that internal time is coordinated with the external world ${ }^{81}$. The SCN then synchronises peripheral circadian clocks throughout the body through multiple signals, with the hypothalamic pituitary adrenal axis, through the hormone cortisol, providing one of the most powerful synchronising signals. As the circadian clock regulates on average about $15 \%$ of the transcriptome of any tissue ${ }^{82-84}$, it has a profound effect on the function of that tissue, resulting in appropriately timed physiology. It is therefore no surprise that sleep and CR disruption, that occurs for example as a consequence of stressors such as shift-work or jet-lag, can contribute to the development of a range of disorders. Much of our evidence comes from the study of night shift workers and offshore workers, where CRs of cortisol can be dampened and shifted ${ }^{85,86}$, and resulting in comorbidity with insomnia, anxiety and depression ${ }^{87}$, and impacting normal metabolism, incidence of cancer and mental health disorders ${ }^{88,89}$. 


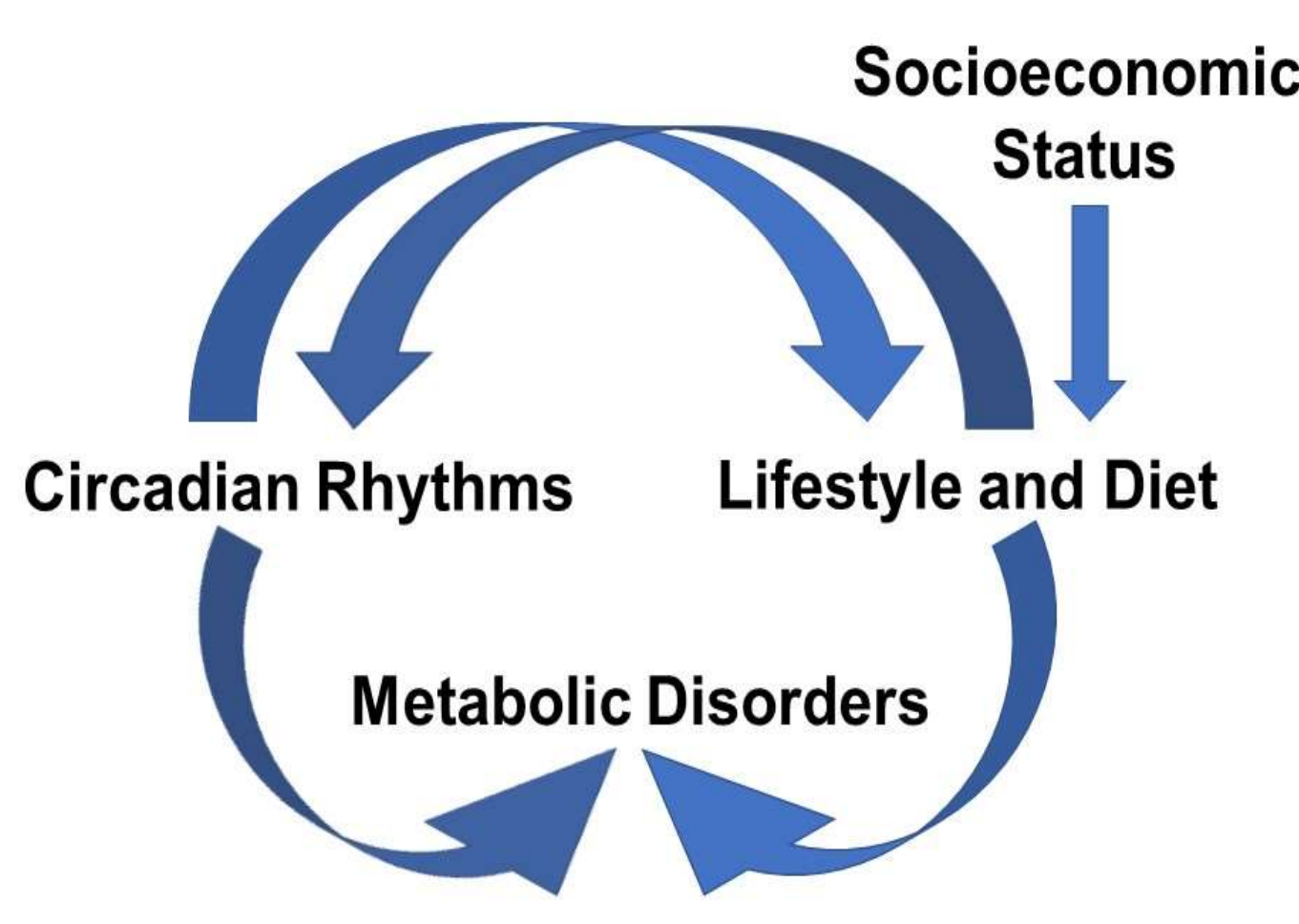

Fig. 3: Theoretical relation between circadian rhythms, socioeconomic status, lifestyle and metabolic disorders.

\section{FUTURE DIRECTIONS AND CONCLUSIONS}

SD have been under intense study in the last two decades and remain a subject of interest at the borders of several disciplines such as psychology, neurology and psychiatry. Incidence and prevalence of SD are increasing, while their determinants as well as their 
associated psychopathological mechanisms are not well understood. More than the other external factors, the interaction between the SES and sleep must be understood better. Living conditions strongly influence the trajectory of SD by inducing allostatic load which affects differently adolescents, adults and older people, in an unknown speed and for a non-determined period. The combined effects of environmental and psychological stressors seem noxious for mood disorders and sleep. Future work should identify the combined effect of psychological factors, stress and lifestyle on the development and progression of SD, such that behavioural and pharmacological interventions, including those promoting a healthy lifestyle, can be implemented to reduce the incidence of SD and develop novel therapies. This would be effective when a full definition of SES is known, allowing researchers of different fields to understand each other and apply mixed methodologies to assess collected data, which can be used by everyone.

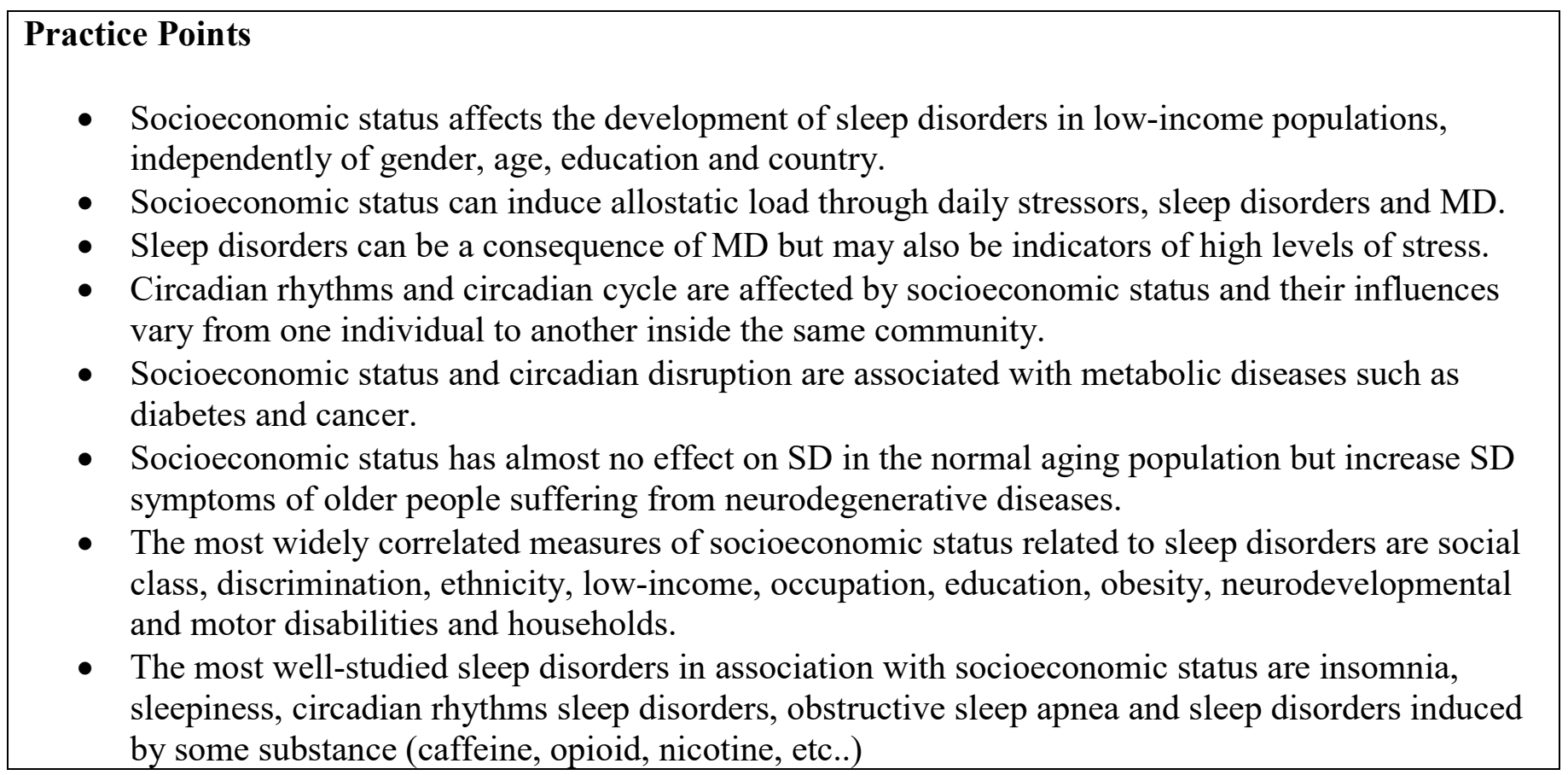




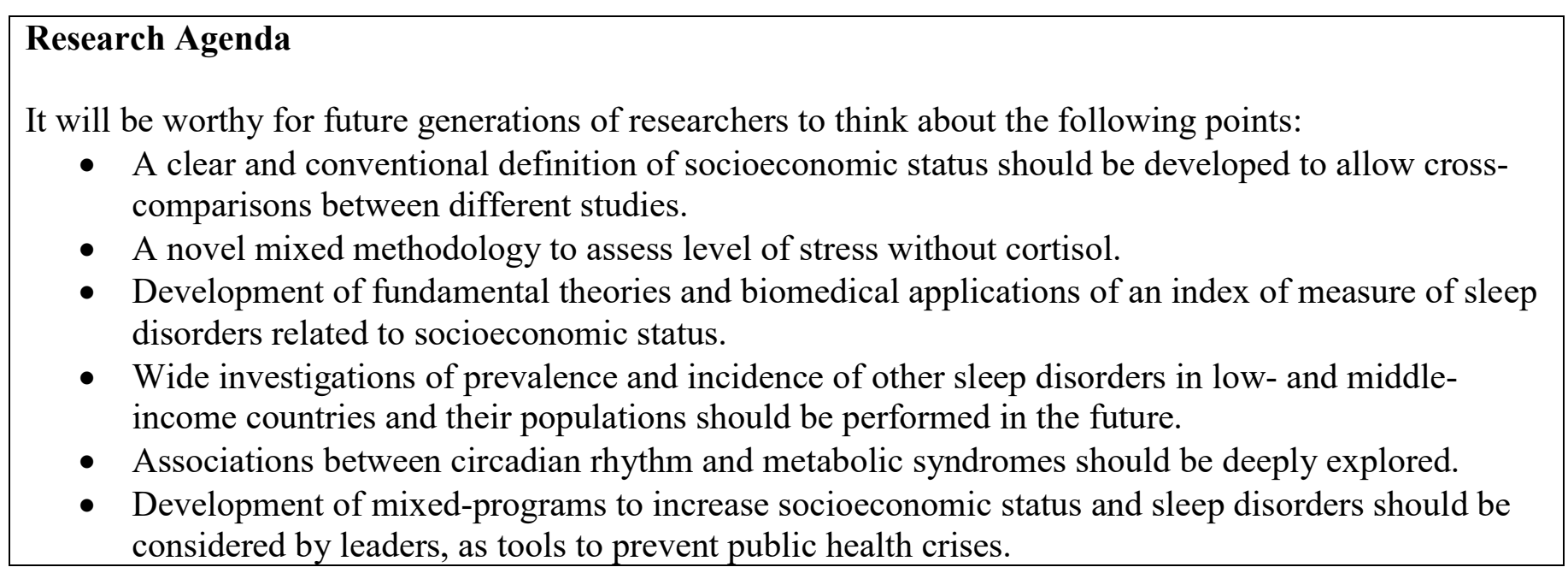

\section{REFERENCES}

1. Garbarino S, Lanteri P, Durando P, Magnavita N, Sannita WG. Co-Morbidity, Mortality, Quality of Life and the Healthcare/Welfare/Social Costs of Disordered Sleep: A Rapid Review. Int J Environ Res Public Health. 2016 Aug 18;13(8).

2. Chen X, Redline S, Shields AE, Williams DR, Williams MA. Associations of allostatic load with sleep apnea, insomnia, short sleep duration, and other sleep disturbances: findings from the National Health and Nutrition Examination Survey 2005 to 2008. Ann Epidemiol. 2014 Aug;24(8):612-9.

3. Borbely AA. A two process model of sleep regulation. Hum Neurobiol. 1982;1(3):195-204.

4. Borbely AA. Sleep regulation. Introduction. Hum Neurobiol. 1982;1(3):161-2.

5. Jan JE, Bax MC, Owens JA, Ipsiroglu OS, Wasdell MB. Neurophysiology of circadian rhythm sleep disorders of children with neurodevelopmental disabilities. Eur J Paediatr Neurol. 2012 Sep;16(5):403-12.

6. Leger D, Ogrizek P. [Review on sleep and awakening disorders]. Rev Med Interne. 2012 Sep;33(9):525-31.

7. Wisden W, Yu X, Franks NP. GABA Receptors and the Pharmacology of Sleep. Handb Exp Pharmacol. 2017 Oct 10.

8. Haba-Rubio J, Marti-Soler H, Tobback N, Andries D, Marques-Vidal P, Waeber G, et al. Sleep characteristics and cognitive impairment in the general population: The HypnoLaus study. Neurology. 2017 Jan 31;88(5):463-469.

9. Riemersma-van der Lek RF, Swaab DF, Twisk J, Hol EM, Hoogendijk WJ, Van Someren EJ. Effect of bright light and melatonin on cognitive and noncognitive function in elderly residents of group care facilities: a randomized controlled trial. JAMA. 2008 Jun 11;299(22):2642-55.

10. Wams EJ, Woelders T, Marring I, van Rosmalen L, Beersma DGM, Gordijn MCM, et al. Linking light exposure and subsequent sleep: a field polysomnography study in humans. Sleep. 2017 Oct 11.

11. Omond S, Ly LMT, Beaton R, Storm JJ, Hale MW, Lesku JA. Inactivity Is Nycthemeral, Endogenously Generated, Homeostatically 
Regulated, and Melatonin Modulated in a Free-Living Platyhelminth Flatworm. Sleep. 2017 Oct 01;40(10).

12. Etindele Sosso F, Hito M, Bern S. Basic activity of neurons in the dark during somnolence induced by anesthesia. J Neurol Neurosci. $2017 ; 8(3)$.

13. Etindele Sosso FA. Visual dot interaction with short-term memory. Neurodegener Dis Manag. 2017 Jun 23.

14. Basner M, Dinges DF. Sleep Duration in the United States 2003-2016:First Signs of Success in the Fight Against Sleep Deficiency? Sleep. 2018 Jan 8 .

15. Felden EP, Leite CR, Rebelatto CF, Andrade RD, Beltrame TS. [Sleep in adolescents of different socioeconomic status: a systematic review]. Rev Paul Pediatr. 2015 Dec;33(4):467-73.

16. Lauderdale DS, Philip Schumm L, Kurina LM, McClintock M, Thisted RA, Chen JH, et al. Assessment of sleep in the National Social Life, Health, and Aging Project. J Gerontol B Psychol Sci Soc Sci. 2014 Nov;69 Suppl 2:S125-33.

17. Etindele Sosso FA, Raouafi S. Brain Disorders: Correlation between Cognitive Impairment and Complex Combination. Mental Health in Family Medicine. 2016;12:215-222.

18. Sosso FE. Neurocognitive Game between Risk Factors, Sleep and Suicidal Behaviour. Sleep Science. 2017;10(2017):41-46.

19. Carson V, Tremblay MS, Chaput JP, Chastin SF. Associations between sleep duration, sedentary time, physical activity, and health indicators among Canadian children and youth using compositional analyses. Appl Physiol Nutr Metab. 2016 Jun;41(6 Suppl 3):S294-302.

20. Gosling JA, Batterham PJ, Glozier N, Christensen H. The influence of job stress, social support and health status on intermittent and chronic sleep disturbance: an 8-year longitudinal analysis. Sleep Med. 2014 Aug;15(8):979-85.

21. Keyes KM, Maslowsky J, Hamilton A, Schulenberg J. The great sleep recession: changes in sleep duration among US adolescents, 19912012. Pediatrics. 2015 Mar;135(3):460-8.

22. Prather AA, Janicki-Deverts D, Adler NE, Hall M, Cohen S. Sleep Habits and Susceptibility to Upper Respiratory Illness: the Moderating Role of Subjective Socioeconomic Status. Ann Behav Med. 2017 Feb;51(1):137-146.

23. Seixas AA, Nunes JV, Airhihenbuwa CO, Williams NJ, Pandi-Perumal SR, James CC, et al. Linking emotional distress to unhealthy sleep duration: analysis of the 2009 National Health Interview Survey. Neuropsychiatr Dis Treat. 2015;11:2425-30.

24. Yazdi Z, Sadeghniiat-Haghighi K, Loukzadeh Z, Elmizadeh K, Abbasi M. Prevalence of Sleep Disorders and Their Impacts on Occupational Performance: A Comparison between Shift Workers and Nonshift Workers. Sleep Disord. 2014;2014:870320.

25. Green MJ, Benzeval M. The development of socioeconomic inequalities in anxiety and depression symptoms over the lifecourse. Social Psychiatry and Psychiatric Epidemiology. 2013 06/04

$06 / 26 /$ received

05/21/accepted;48(12):1951-1961. Available from: PMC

26. Hoebel J, Maske UE, Zeeb H, Lampert T. Social Inequalities and Depressive Symptoms in Adults: The Role of Objective and Subjective Socioeconomic Status. PLoS ONE. 2017 01/20

06/02/received

12/21/accepted;12(1):e0169764. Available from: PMC

27. Hoggard LS, Hill LK. Examining How Racial Discrimination Impacts Sleep Quality in African Americans: Is Perseveration the Answer? Behav Sleep Med. 2018 Sep-Oct;16(5):471-481.

28. Green MJ, Espie CA, Benzeval M. Social class and gender patterning of insomnia symptoms and psychiatric distress: a 20-year prospective cohort study. BMC Psychiatry. 2014 May 25;14:152.

29. Okun ML, Tolge M, Hall M. Low socioeconomic status negatively affects sleep in pregnant women. J Obstet Gynecol Neonatal Nurs. 2014 Mar-Apr;43(2):160-7.

30. Chen KM, Lin MH, Wang YC, Li CH, Huang HT. Psychological and socioeconomic health of community-dwelling older adults. Int J Psychol. 2013;48(6):1038-49. 
31. Karlamangla AS, Friedman EM, Seeman TE, Stawksi RS, Almeida DM. Daytime trajectories of cortisol: demographic and socioeconomic differences--findings from the National Study of Daily Experiences. Psychoneuroendocrinology. 2013 Nov;38(11):2585-97.

32. Stawski RS, Cichy KE, Piazza JR, Almeida DM. Associations among daily stressors and salivary cortisol: findings from the National Study of Daily Experiences. Psychoneuroendocrinology. 2013 Nov;38(11):2654-65.

33. Tom SE, Berenson AB. Associations between poor sleep quality and psychosocial stress with obesity in reproductive-age women of lower socioeconomic status. Womens Health Issues. 2013 Sep-Oct;23(5):e295-300.

34. Green MJ, Espie CA, Hunt K, Benzeval M. The longitudinal course of insomnia symptoms: inequalities by sex and occupational class among two different age cohorts followed for 20 years in the west of Scotland. Sleep. 2012 Jun 1;35(6):815-23.

35. Lo CM, Lee PH. Prevalence and impacts of poor sleep on quality of life and associated factors of good sleepers in a sample of older Chinese adults. Health Qual Life Outcomes. 2012 Jun 18;10:72.

36. Gureje O, Oladeji BD, Abiona T, Makanjuola V, Esan O. The natural history of insomnia in the Ibadan study of ageing. Sleep. 2011 Jul 1;34(7):965-73.

37. Hawkley LC, Lavelle LA, Berntson GG, Cacioppo JT. Mediators of the relationship between socioeconomic status and allostatic load in the Chicago Health, Aging, and Social Relations Study (CHASRS). Psychophysiology. 2011 Aug;48(8):1134-45.

38. Goodin BR, McGuire L, Smith MT. Ethnicity moderates the influence of perceived social status on subjective sleep quality. Behav Sleep Med. 2010;8(4):194-206.

39. Kumari M, Badrick E, Chandola T, Adler NE, Epel E, Seeman T, et al. Measures of social position and cortisol secretion in an aging population: findings from the Whitehall II study. Psychosom Med. 2010 Jan;72(1):27-34.

40. Phelan JC, Link BG, Tehranifar P. Social conditions as fundamental causes of health inequalities: theory, evidence, and policy implications. J Health Soc Behav. 2010;51 Suppl:S28-40.

41. Tomfohr LM, Ancoli-Israel S, Dimsdale JE. Childhood socioeconomic status and race are associated with adult sleep. Behav Sleep Med. 2010;8(4):219-30.

42. Friedman EM, Love GD, Rosenkranz MA, Urry HL, Davidson RJ, Singer BH, et al. Socioeconomic status predicts objective and subjective sleep quality in aging women. Psychosom Med. 2007 Sep-Oct;69(7):682-91.

43. Adler NE, Epel ES, Castellazzo G, Ickovics JR. Relationship of subjective and objective social status with psychological and physiological functioning: preliminary data in healthy white women. Health Psychol. 2000 Nov;19(6):586-92.

44. Hall M, Bromberger J, Matthews K. Socioeconomic status as a correlate of sleep in African-American and Caucasian women. Ann N Y Acad Sci. 1999;896:427-30.

45. Van Cauter E, Spiegel K. Sleep as a mediator of the relationship between socioeconomic status and health: a hypothesis. Ann N Y Acad Sci. 1999;896:254-61.

46. Anguera JA, Boccanfuso J, Rintoul JL, Al-Hashimi O, Faraji F, Janowich J, et al. Video game training enhances cognitive control in older adults. Nature. 2013 Sep 5;501(7465):97-101.

47. Colzato LS, van den Wildenberg WP, Zmigrod S, Hommel B. Action video gaming and cognitive control: playing first person shooter games is associated with improvement in working memory but not action inhibition. Psychol Res. 2013 Mar;77(2):234-9.

48. Beland SG, Postuma RB, Latreille V, Bertrand JA, Panisset M, Chouinard S, et al. Observational Study of the Relation between Parkinson's Disease and Sleep Apnea. J Parkinsons Dis. 2015;5(4):805-11.

49. Bertrand JA, McIntosh AR, Postuma RB, Kovacevic N, Latreille V, Panisset M, et al. Brain Connectivity Alterations Are Associated with the Development of Dementia in Parkinson's Disease. Brain Connect. 2016 Apr;6(3):216-24.

50. Etindele Sosso FA. Negative Involvement of the Working Environment in the Occurrence of Cognitive Disorders. Transl Biomed. $2017 ; 8: 2$.

51. Baron KG, Reid KJ. Circadian misalignment and health. Int Rev Psychiatry. 2014 Apr;26(2):139-54.

52. Barazzetta M, Ghislandi S. Family Income and Material Deprivation: Do They Matter for Sleep Quality and Quantity in Early Life. Sleep. 


\section{Nov 28.}

53. Basner M, Spaeth AM, Dinges DF. Sociodemographic characteristics and waking activities and their role in the timing and duration of sleep. Sleep. 2014 Dec 01;37(12):1889-906.

54. Darin-Mattsson A, Fors S, Kåreholt I. Different indicators of socioeconomic status and their relative importance as determinants of health in old age. International Journal for Equity in Health. 2017 09/26

$01 / 31 /$ received

09/21/accepted;16:173. Available from: PMC

55. Bonke J. Trends in short and long sleep in Denmark from 1964 to 2009, and the associations with employment, SES (socioeconomic status) and BMI. Sleep Med. 2015 Mar;16(3):385-90.

56. Matthews KA, Gallo LC. Psychological Perspectives on Pathways Linking Socioeconomic Status and Physical Health. Annual review of psychology. 2011;62:501-530. Available from: PMC

57. Fiske A, Wetherell JL, Gatz M. Depression in older adults. Annu Rev Clin Psychol. 2009;5:363-89.

58. Pereira D, Gross S, Elfering A. Social Stressors at Work, Sleep, and Recovery. Appl Psychophysiol Biofeedback. 2016 Mar;41(1):93-101.

59. Roskoden FC, Kruger J, Vogt LJ, Gartner S, Hannich HJ, Steveling A, et al. Physical Activity, Energy Expenditure, Nutritional Habits, Quality of Sleep and Stress Levels in Shift-Working Health Care Personnel. PLoS One. 2017;12(1):e0169983.

60. Stringhini S, Berkman L, Dugravot A, Ferrie JE, Marmot M, Kivimaki M, et al. Socioeconomic Status, Structural and Functional Measures of Social Support, and Mortality: The British Whitehall II Cohort Study, 1985-2009. American Journal of Epidemiology. 2012 04/24

04/18/received

11/10/accepted;175(12):1275-1283. Available from: PMC

61. Wodtke GT. Social Class and Income Inequality in the United States: Ownership, Authority, and Personal Income Distribution from 1980 to 2010. AJS; American journal of sociology. 2016;121(5):1375-1415. Available from: PMC

62. Vonneilich N, Jöckel K-H, Erbel R, Klein J, Dragano N, Siegrist J, et al. The mediating effect of social relationships on the association between socioeconomic status and subjective health - results from the Heinz Nixdorf Recall cohort study. BMC Public Health. 2012 04/17 $11 / 15 /$ received

04/17/accepted;12:285-285. Available from: PMC

63. Van Dyke ME, Vaccarino V, Quyyumi AA, Lewis TT. Socioeconomic status discrimination is associated with poor sleep in AfricanAmericans, but not Whites. Soc Sci Med. 2016 Mar;153:141-7.

64. Russ TC, Stamatakis E, Hamer M, Starr JM, Kivimäki M, Batty GD. Socioeconomic status as a risk factor for dementia death: individual participant meta-analysis of 86508 men and women from the UK. The British Journal of Psychiatry. 2013 08/14/received

$02 / 18 /$ revised

02/19/accepted;203(1):10-17. Available from: PMC

65. Slopen N, Williams DR. Discrimination, other psychosocial stressors, and self-reported sleep duration and difficulties. Sleep. 2014 Jan $01 ; 37(1): 147-56$.

66. Canuto R, Garcez AS, Olinto MT. Metabolic syndrome and shift work: a systematic review. Sleep Med Rev. 2013 Dec;17(6):425-31.

67. Anders MP, Breckenkamp J, Blettner M, Schlehofer B, Berg-Beckhoff G. Association between socioeconomic factors and sleep quality in an urban population-based sample in Germany. Eur J Public Health. 2014 Dec;24(6):968-73.

68. Bagley EJ, Fuller-Rowell TE, Saini EK, Philbrook LE, El-Sheikh M. Neighborhood Economic Deprivation and Social Fragmentation:

Associations With Children's Sleep. Behav Sleep Med. 2016 Dec 09:1-13.

69. Grandner MA, Jackson NJ, Izci-Balserak B, Gallagher RA, Murray-Bachmann R, Williams NJ, et al. Social and Behavioral Determinants of Perceived Insufficient Sleep. Front Neurol. 2015;6:112.

70. Castro LS, Castro J, Hoexter MQ, Quarantini LC, Kauati A, Mello LE, et al. Depressive symptoms and sleep: a population-based 
polysomnographic study. Psychiatry Res. 2013 Dec 30;210(3):906-12.

71. Leggett A, Burgard S, Zivin K. The Impact of Sleep Disturbance on the Association Between Stressful Life Events and Depressive Symptoms. J Gerontol B Psychol Sci Soc Sci. 2016 Jan;71(1):118-28.

72. Milojevich HM, Lukowski AF. Sleep and Mental Health in Undergraduate Students with Generally Healthy Sleep Habits. PLoS One. 2016;11(6):e0156372.

73. Prairie BA, Wisniewski SR, Luther J, Hess R, Thurston RC, Wisner KL, et al. Symptoms of depressed mood, disturbed sleep, and sexual problems in midlife women: cross-sectional data from the Study of Women's Health Across the Nation. J Womens Health (Larchmt). 2015 Feb;24(2):119-26.

74. Jiang Y, Yang M, Wu H, Song H, Zhan F, Liu S, et al. The relationship between disease activity measured by the BASDAI and psychological status, stressful life events, and sleep quality in ankylosing spondylitis. Clin Rheumatol. 2015 Mar;34(3):503-10.

75. Zaslavsky O, LaCroix AZ, Hale L, Tindle H, Shochat T. Longitudinal changes in insomnia status and incidence of physical, emotional, or mixed impairment in postmenopausal women participating in the Women's Health Initiative (WHI) study. Sleep Med. 2015 Mar;16(3):364-71.

76. Etindele Sosso F, Raouafi S. Appropriate Sleep Duration and Physical Activity Modulate Cognitive Improvement. J Sleep Disor: Treat Care 5: 4. Journal of Sleep Disorders:treatment and care. 2016;5(4).

77. Groch S, Preiss A, McMakin DL, Rasch B, Walitza S, Huber R, et al. Targeted Reactivation during Sleep Differentially Affects Negative Memories in Socially Anxious and Healthy Children and Adolescents. J Neurosci. 2017 Mar 01;37(9):2425-2434.

78. Hayley AC, Downey LA, Stough C, Sivertsen B, Knapstad M, Overland S. Social and emotional loneliness and self-reported difficulty initiating and maintaining sleep (DIMS) in a sample of Norwegian university students. Scand J Psychol. 2017 Feb;58(1):91-99.

79. Price AMH, Quach J, Wake M, Bittman M, Hiscock H. Cross-sectional sleep thresholds for optimal health and well-being in Australian 4-9year-olds. Sleep Med. 2016 Jun;22:83-90.

80. Reppert SM, Weaver DR. Coordination of circadian timing in mammals. Nature. 2002 Aug 29;418(6901):935-41.

81. Klein DC, Moore RY, Reppert SM. Suprachiasmatic nucleus : the mind's clock. New York: Oxford University Press; 1991. p. xvi, 467 p.

82. Panda S, Antoch MP, Miller BH, Su AI, Schook AB, Straume M, et al. Coordinated transcription of key pathways in the mouse by the circadian clock. Cell. 2002 May 03;109(3):307-20.

83. Duffield GE, Best JD, Meurers BH, Bittner A, Loros JJ, Dunlap JC. Circadian programs of transcriptional activation, signaling, and protein turnover revealed by microarray analysis of mammalian cells. Curr Biol. 2002 Apr 02;12(7):551-7.

84. Kornmann B, Schaad O, Bujard H, Takahashi JS, Schibler U. System-driven and oscillator-dependent circadian transcription in mice with a conditionally active liver clock. PLoS Biol. 2007 Feb;5(2):e34.

85. Harris A, Waage S, Ursin H, Hansen AM, Bjorvatn B, Eriksen HR. Cortisol, reaction time test and health among offshore shift workers. Psychoneuroendocrinology. 2010 Oct;35(9):1339-47.

86. Touitou Y, Motohashi Y, Reinberg A, Touitou C, Bourdeleau P, Bogdan A, et al. Effect of shift work on the night-time secretory patterns of melatonin, prolactin, cortisol and testosterone. Eur J Appl Physiol Occup Physiol. 1990;60(4):288-92.

87. Kalmbach DA, Pillai V, Cheng P, Arnedt JT, Drake CL. Shift work disorder, depression, and anxiety in the transition to rotating shifts: the role of sleep reactivity. Sleep Med. 2015 Dec;16(12):1532-8.

88. Jagannath A, Taylor L, Wakaf Z, Vasudevan SR, Foster RG. The genetics of circadian rhythms, sleep and health. Hum Mol Genet. 2017 Oct 1;26(R2):R128-R138.

89. Jagannath A, Peirson SN, Foster RG. Sleep and circadian rhythm disruption in neuropsychiatric illness. Curr Opin Neurobiol. 2013 Oct;23(5):888-94. 